\title{
Analyzing regulatory framework for carbon capture and storage (CCS) technology development: A case study approach
}

\author{
Mac OSAZUWA-PETERS, Margot HURLBERT \\ University of Regina, Canada
}

\begin{abstract}
:
Aim: This article provides insight into the portfolio of regulations advancing Carbon Capture and Storage (CCS) deployment. Using a taxonomy of policy portfolio tools adapted for regulations specific to CCS, this research identifies regulatory gaps as well as supports for CCS projects.

Design / Research methods: Through a case study approach, this article analyzes the regulatory provisions in six jurisdictions (Texas, North Dakota, the U.S, Saskatchewan, Alberta and Canada) which have a successful CCS facility. Analyzing the provisions and content of regulations in these jurisdictions, this article highlights regulatory supports or areas of gaps for CCS projects in each jurisdiction.
\end{abstract}

Conclusions / findings: There is no uniform definition or categorization of $\mathrm{CO}_{2}$ as a hazard, waste, pollutant or commodity across jurisdictions. This has serious impact on $\mathrm{CO}_{2}$ transport, especially across jurisdictions. It also impacts the administration of storage systems for CCS facilities. Regulations focusing primarily on technical aspects of CCS including capture, transport, and liability predominate while there are less regulatory provisions for the financial aspects of CCS technology as well as public engagement and support. While capital grants and emission and tax credits are the predominant financial issues covered in regulations, contract for differences, streamlining emission trading across borders and enhancing cooperation and multilevel engagement in CCS warrant more attention.

Originality / value of the article: Many scenarios to maintain global warming below 2 degrees Celsius require combinations of new technology including CCS. The focus on CCS cost as a barrier to deployment overshadows the needs for regulatory support as a means of reducing uncertainties and derisking CCS investments.

Keywords: Carbon Capture and Storage (CCS), policy portfolio, regulatory framework, public engagement

JEL: L59, Q52, R52

Contact details: Mac Osazuwa-Peters, Margot Hurlbert, 309.1 Johnson Shoyama School Of Public Policy, 3rd Floor, College Avenue Campus, 2155 College Avenue, University Of Regina, E-mail: Mac.Osazuwa-Peters@Uregina.ca (Mac Osazuwa-Peters), margot.hurlbert@uregina.ca (Margot Hurlbert).

Received: 15.06.2019, Revised: 02.01.2020, Revised: 08.03.2020, Accepted: 15.03.2020 doi: http://dx.doi.org/10.29015/cerem.834 


\section{Mac OSAZUWA-PETERS, Margot HURLBERT}

\section{Introduction}

In the last decade, carbon capture and storage (CCS) technology has evolved in several respects. In this period, in comparison with other greenhouse gas (GHG) emissions abatement technologies and options, CCS has emerged as one of few technologies capable of achieving GHG emissions abatement targets in the industrial sector as well as conventional fossil fuel power generation plants (Sawyer et al. 2008; US Department of Energy 2016; IEA 2019). But although it is now generally agreed that CCS technology can play a critical role in carbon abatement efforts in the industrial sector (Sawyer et al. 2008; US Department of Energy 2016; IEA 2019), the increase in the deployment of renewables have challenged its usefulness in the power sector. On this point, findings from the International Energy Agency (IEA) (2017) are instructive: while renewables have increased their share of global energy generation, increase in demand and consumption of fossil fuels, especially from the developing world, is eroding gains made in terms of GHG emissions reduction. In other words, dependence on fossil fuel will not slow down in the short term.

Four factors - global economic growth fueled by industrialization; an increase in global energy demand and consumption, lower fossil fuel prices and weaker energy efficiency outcomes; and the suitability of CCS technology in industrial applications - has made CCS an important tool in any effort to cut GHG emissions, especially at the rate and scale required (IEA 2018a, 2018b). Hence, many climate mitigation scenarios to limit our world to $450 \mathrm{ppm}$ of carbon in the atmosphere and maintain global warming below 2 degrees Celsius now rely on a combination of new technologies including CCS (Edelenbosch et al. 2016; Popp et al. 2014, 2017; Koelbl 2014; Scott et al. 2004; den Elzen 2008), renewable, and to a lesser extent nuclear (Tavoni et al. 2012), although there are contrary opinions (de Coninck et al. 2014). Several authors argue that carbon emissions will have to be phased out at unprecedented levels unless CCS and bio-energy CCS (BECCS) are utilized (Blanford et al. 2014; Kanudia et al. 2014). BECCS utilizes biodegradable plant materials as feedstock in producing energy. Applying CCS technology to bioenergy production (BECCS) further reduces the level of emissions in the energy system. In 
the energy and transportation sectors, many future scenarios widely use BECCS (Edelenbosch et al. 2016; Riahi et al. 2017; van Vuuren et al. 2016). While conventional CCS technology (that is, CCS technology in fossil fuel plants) has been demonstrated at commercial scale, BECCS has had one small-scale demonstration facility (Kemper 2015).

Successful CCS development has been sparse, and its deployment far less than anticipated when the Intergovernmental Panel on Climate Change (IPCC) endorsed it as one of several technologies supporting a lower carbon future (Choptiany et al. 2014). Many consider CCS technology as an emerging, new technology of which public acceptance has been at issue (Markusson et al. 2011; Sanchez, Kammen 2016) and a barrier to implementation. Also, the cost of developing CCS technology at commercial scale has been seen by many as challenging the case for its use (World Resource Institute 2011; Napp et al. 2014; Budinis et al. 2018). CCS deployment may be advanced by policies establishing a carbon price and or market, but such policies need regulations as foundations. There has been little discussion of CCS regulations in the literature. Using a taxonomy of policy portfolio tools adapted for regulations specific to CCS, this research identifies regulatory gaps as well as supports for CCS projects.

\subsection{Regulations - why important for CCS development}

Regulations are grand statements providing contexts for action. Also, they define when and how to act; are often the spine and structure which ground action in relation to a defined objective. Without regulations, certainty becomes quite difficult to ascertain. Therefore, regulations provide some measure of guaranty by reducing uncertainty. As with other issues of social, economic and political relevance, CCS requires such solid foundations to guarantee certainty in action and in outcomes. Hence, in relation to CCS technology, the IRGC (2008) stated: "Large-scale CCS deployment will require the creation of a regime to manage risks and supporting policies to facilitate technology investment" and it believes that developing supporting regulations play an important role in that.

Further, regulations help to ensure that policies and actions on CCS technology development do not automatically follow the political circle. This is emphasized as 
important by the Global CCS Institute (2017: 36), saying: "securing policy certainty via a government commitment that has been demonstrated to extend beyond political cycles and to be resilient to conflicting political demands" is crucial for projects that have long term development timelines. This leads to yet another important point: regulations form the bedrock on which policies are built. ${ }^{1}$

Interestingly, in Saskatchewan for example, the deployment of CCS technology was advanced without a CCS specific regulation. This highlights the unique status of CCS as a technology in relation to regulations: as an integrated technology, it is new, but the various components making up the CCS technology chain currently exist and may already be covered by existing regulations. So, in Saskatchewan, the province deployed CCS technology by relying on regulations supporting its component parts rather than creating CCS specific technologies.

Saskatchewan was first-mover case, being the first commercial scale postcombustion CCS plant in the world. From a regulatory standpoint, Saskatchewan's first-mover CCS project provides useful context for gauging what is required, what works and how to improve current regulatory systems meant to accelerate CCS deployments in other places in the world. So, while the Saskatchewan case demonstrates one way to speed up CCS deployment by bypassing the perpetual winding legislative loops associated with developing new regulations, the novelty of CCS in its form as an integrated technology suggests that new challenges, risks, and uncertainties that old regulations do not adequately make provisions for may arise. Also, as CCS technology matures, the overall regulatory architecture underpinning it should understandably evolve, necessitating revisions. Thus, there is a need to review the current portfolio of regulations of CCS technology, especially now that its deployment needs to be increased. In this article, we have adapted the policy implementation taxonomy toolbox for reviewing policies as developed by Howlett (2019) as a framework for reviewing regulations governing CCS development.

\footnotetext{
${ }^{1}$ In the literature, 'regulations' and 'policies' are sometimes used interchangeably or even together. In this article, they are distinct. Regulations, as used in this article, are legally binding pieces of legislations advanced by state and its institutions to support specific goals. These are different from policies which are the means for achieving the objectives in the regulations.
} 


\subsection{Policy implementation tool taxonomy}

The policy implementation tool taxonomy was developed to explain what types of policy instruments governments choose when tackling policy problems and why. The relevance of this question is in the fact that although there is usually a wider range of instrument options to choose from, governments always seem to choose from a limited set of options Howlett (2019). One reason for this is that the choice of policy instrument selected is related to the mode of governance in the state. Another, and closely related to this, is that the choice of policy instrument is a function of the "resources governments have at their disposal in developing the means to attain policy objectives" (Howlett 2009: 81). These resources which Howlett (2019) groups into the following categories: organization, authority, treasure and information form the policy implementation taxonomy (see Figure 1 below).

Figure 1. Policy portfolio implementation tool taxonomy

\begin{tabular}{|c|c|c|c|c|}
\hline & \multicolumn{4}{|l|}{ Goveming Resource } \\
\hline & Information & Authority & Treasure & Organization \\
\hline \multirow[t]{5}{*}{ Substance } & Advice & Licenses & Subsidies & Bureancracies \\
\hline & Training & User charges & Grants & Public enterprises \\
\hline & Reporting & Regulation & Loans & Quangos \\
\hline & Education & Self-regulation & $\begin{array}{l}\text { Tax } \\
\quad \text { expenditures }\end{array}$ & \\
\hline & $\begin{array}{l}\text { Advertising } \\
\text { Surveys }\end{array}$ & $\begin{array}{r}\text { Vouchers } \\
\text { Quotas }\end{array}$ & $\begin{array}{l}\text { Program } \\
\text { funding }\end{array}$ & \\
\hline \multicolumn{5}{|l|}{ Purpose } \\
\hline \multirow[t]{3}{*}{ Process } & $\begin{array}{l}\text { Information-suppression } \\
\text { (Censorship) }\end{array}$ & $\begin{array}{l}\text { Advisory group } \\
\text { creation }\end{array}$ & Interest-group funding & $\begin{array}{l}\text { Administrative } \\
\text { re-organization }\end{array}$ \\
\hline & $\begin{array}{l}\text { Information- release } \\
\text { (Access to Information) }\end{array}$ & $\begin{array}{l}\text { Interest group or } \\
\text { party bans }\end{array}$ & Campaign funding & $\begin{array}{l}\text { Administrative delay } \\
\text { and obfuscation }\end{array}$ \\
\hline & & Denial of access & Denial of funding & \\
\hline
\end{tabular}

Source: Howlett (2019).

Although Howlett's policy implementation tool taxonomy was created in the context of policies and not regulations, in this study we have adapted it based on the argument advanced already that policies are developed based on regulations. For example, when governments develop policies that sanction certain actions or drive 
actions through coercion, they are using their authority as a resource. However, implicit in that process is the assumption that the policies are backed by regulations that spell out consequences for acting in support or in opposition to the government's ability to meet its expected objective. This underlying logic means therefore that regulations can very well be categorized along the same lines as the policy taxonomy. Thus, as shown in Table 1 below, this study adapts the policy implementation tool taxonomy by merging the authority and organizational categories. The authority category, according to Howlett (2019), involve the use of coercive force by government. This can be achieved by the government through compliance monitoring by its bureaucracy (according to Howlett, the bureaucracy represents the government's organizational resource). Therefore, we conclude that organizational resources work to enforce authority.

In the following section we discuss how CCS regulations and the issues they cover map into this framework.

\section{Method}

This study is explorative in scope and is based on a case study research design. Two states (in the United States), and two provinces (in Canada) with successful CCS plants, and their associated federal jurisdictions (United States and Canada) were examined, for a total of six jurisdictions.

The study was advanced in two stages. The first stage involved the identification of issues or challenges facing CCS technology in the literature. This stage relied on secondary data which it collected using a systematic literature review and then followed by a content analysis. Databases such as SCOPUS and Google Scholar were accessed and searched for published peer-reviewed articles. For this step, search phrases used included: "CCS regulation," "CCS policy issues," "CCS and Saskatchewan," "CCS and Texas," "CCS and North Dakota," "CCS and Alberta," "CCS policy," and "future CCS development." Once articles are found containing discussions of issues requiring regulation, they are included in a database on NVivo software (for qualitative analysis). A search of other relevant articles was done in the 
reference section of selected articles to find more articles. The International CCS Knowledge Centre provided access to grey literature from its own network of mostly transnational organizations involved with CCS technology, including the International Energy Agency (IEA), the Global CCS Institute, and the United Nations Framework Convention on Climate Change (UNFCCC). Together, a total of 117 articles discussing issues associated with CCS technology, including barriers and policy actions were found and included in the study database on NVivo. The articlesselected we analyzed on NVivo to identify key issues related to CCS technology requiring regulatory support. These issues were categorized following the policy implementation tool taxonomy framework by Howlett (2019).

The second stage involved a content analysis of existing regulations in the six jurisdictions (Canada (Federal), Alberta, Saskatchewan, the U.S (Federal), Texas and North Dakota). Some of the articles located in step one, referred to specific CCS regulations in different countries of the world, but most regulations were identified and collected by searching directly in parliamentary databases of the target jurisdictions. A total of 76 existing regulations were used for the analysis after exclusion criteria was applied. These regulations were thematically analyzed based on the developed policy implementation tool taxonomy framework to reveal aspects of CCS technology that are currently covered as well as areas where there is a gap in regulatory coverage.

All materials collected (both for the literature review and the analysis of regulations) were analyzed using NVivo software. The issues found in the literature were operationalized on NVivo as cases. Each case represents an aspect or activity in a typical CCS chain that has been identified in the literature as requiring some level of regulatory support (see Appendix I - Coding guide). Through an analysis of the content of these articles on NVivo, sixteen different issues were found in the literature (making sixteen case nodes on NVivo).

The next step involved coding ${ }^{2}$ the regulations collected against each case. This way, this study identified which regulations make provisions for which CCS issue. This was done using NVivo software as well. Thus, the analysis of cases serves as

\footnotetext{
${ }^{2}$ Only regulations with direct bearing on the issues in the framework are coded. In fact, some regulations with only vague connection were excluded from the project.
} 
the basis for developing insight into the portfolio of regulations advancing CCS deployment.

\section{Results}

A total of 76 regulations were collected from the six jurisdictions in the study. However, following coding on NVivo, 37 of those were excluded for being too remotely connected to CCS technology or components of it (such as EOR); being more connected to the environment in general; not being in force; and having amendments that nullify its provisions in a different regulation. Thus, in the end, 39 regulations from six jurisdictions were used $(n=49)$ (See Figure 2 below for distribution per jurisdiction).

\section{Figure 2. Number of CCS regulations per jurisdiction}

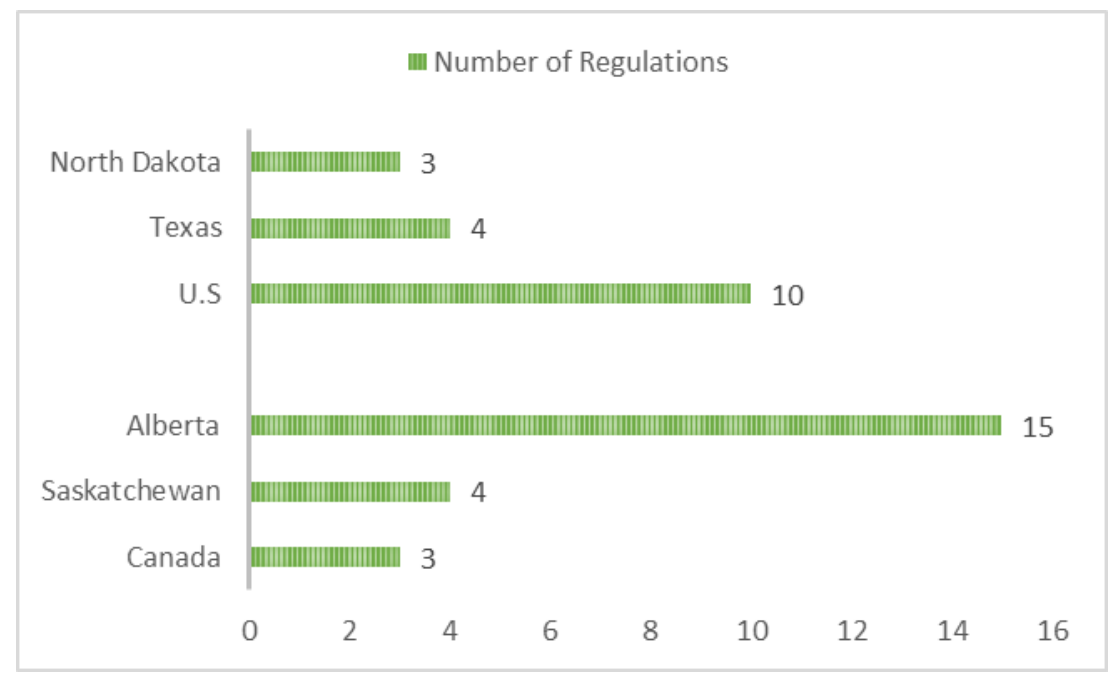

Source: Compiled by the author from NVivo analysis of regulations.

Issues related to CCS technology found in the literature were grouped into three core categories shown in Figure 3 below. 
Figure 3. The three pillars in CCS technology development and acceleration

\begin{tabular}{l} 
Financials \\
1. Capital Grant \\
2. CCS Certificate \\
3. Contract of Difference \\
4. Emissiosn and Tax Credits \\
5. Loan Guarantees \\
6. Price Mechanisms \\
\hline
\end{tabular}

Technical
1. Capture
2. Closure, Post-closure \&
Decommissioning
3. CO2 Classification
4. CO2 Injection
5. Site Selection
6. Storage and Long-term Liability
7. Transport

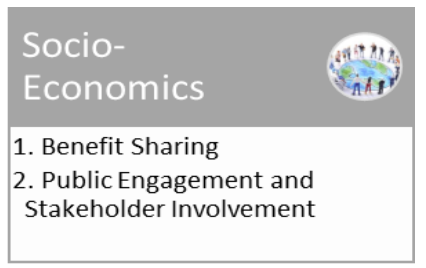

Source: Compiled by this author from literature review. ${ }^{3}$

Table 1. Taxonomy of regulations

\begin{tabular}{|l|l|l|}
\hline & \multicolumn{2}{|c|}{ Regulatory Tools } \\
\hline CCS Activities and Regulatory Issues & $\begin{array}{l}\text { Governing } \\
\text { Resources } \\
\text { Required (Howlett } \\
\mathbf{2 0 1 9}\end{array}$ & $\begin{array}{l}\text { Regulatory Tools } \\
\text { Required }\end{array}$ \\
\hline $\begin{array}{l}\mathrm{CO}_{2} \text { classification (hazardous material, } \\
\text { pollutant, waste), transport, CCS capture, } \\
\text { Post-closure and decommissioning, } \mathrm{CO}_{2} \\
\text { injection, site selection, storage and long- } \\
\text { term liability }\end{array}$ & Organization & Technical Authority \\
\cline { 2 - 3 } $\begin{array}{l}\text { Capital grants, CCS certificate, contract for } \\
\text { difference, emissions and tax credits, loan } \\
\text { guarantees, price mechanism }\end{array}$ & Treasure & Financial \\
\hline $\begin{array}{l}\text { Public engagement and stakeholder } \\
\text { involvement, benefit sharing }\end{array}$ & Informational & $\begin{array}{l}\text { Information } \\
\text { dissemination and } \\
\text { public engagement }\end{array}$ \\
\hline
\end{tabular}

Source: Compiled by this author; adapted from Howlett (2019).

Through the process of coding the selected regulations, this study found that the technical issues required the use of organizational and authoritative resources to either define and set standards or monitor compliance. Hence, regulations covering these issues not only need to be authoritative but also technically sound. Therefore, these issues were mapped into our regulatory taxonomy framework as technical authority. The treasure related issues were covered by financial regulations while regulations with provisions for public engagement corresponded to informational.

\footnotetext{
${ }^{3}$ Please see Appendix VI for literature list.
} 
Thus, as adapted here, and shown in Table 1, instead of four categories, there were three: technical authority, financial, and information dissemination / public engagement.

Based on the coding results shown in Figure 4, reference to technical issues dominate CCS regulations with $\mathrm{CO}_{2}$ capture, storage and long-term liability and $\mathrm{CO}_{2}$ injection having significant regulatory attention. The category to receive the least regulatory coverage is the informational category. In fact, in Texas, there is no reference to any public engagement and informational issues. In terms of financial or economic issues, tax credit, capital grants and capital grants dominated.

\section{Figure 4. NVivo coding by location and regulatory taxonomy}

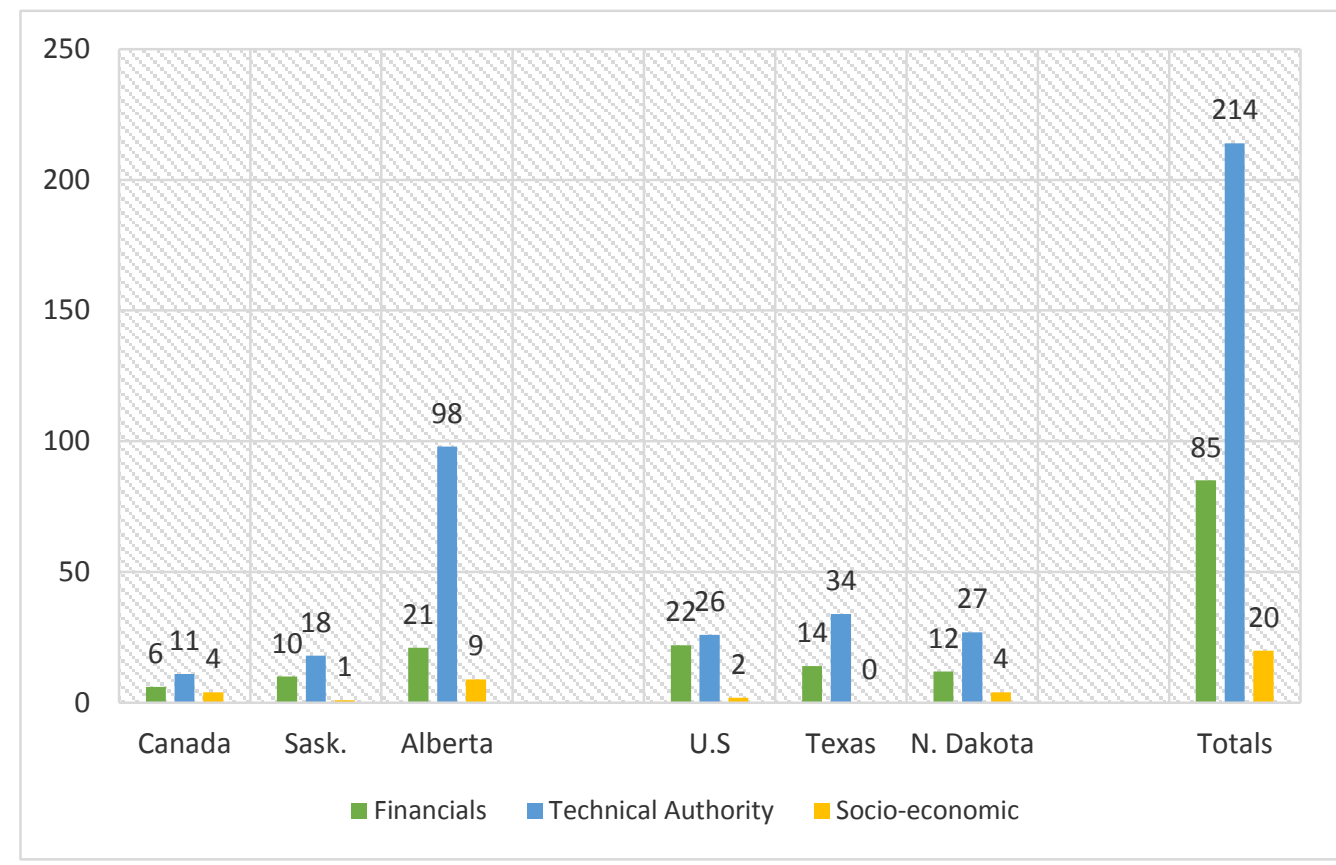

Source: Compiled by the authors from NVivo analysis. 


\section{Discussion and analysis}

The results of the analysis, using the adapted regulatory taxonomy tool framework shown in Table 1, are described subsequently. This analysis paints a picture of the regulatory portfolio supporting CCS technology and gaps that would need to be filled to provide more certainty for CCS stakeholders and accelerate deployment.

\subsection{Technical authority}

The taxonomy of 'technical authority' concerns defining, setting standards, and monitoring compliance. Thus, the issues under this taxonomy are mostly technical, requiring the government to use their authority to determine standards. Some of the earliest obstacles to developing CCS technology were of a technical nature, hence regulations focusing on technical issues including $\mathrm{CO}_{2}$ classification, storage safety, $\mathrm{CO}_{2}$ injection and transport, site closure, decommissioning, and long-term liability are described under this taxonomy. In Figure 3 below, we show the number of regulations making provisions for these technical issues across the six jurisdictions.

Figure 5. Distribution of references to technical issues in regulations

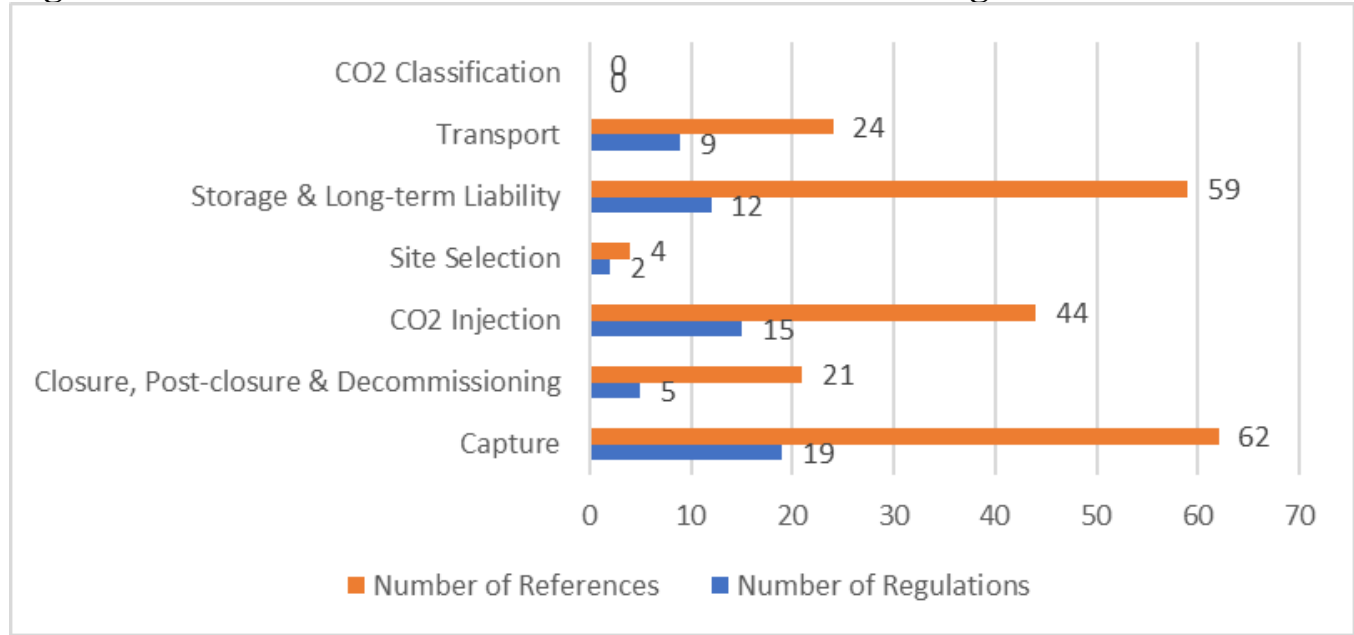

Source: Compiled by this author from NVivo analysis. 


\section{Mac OSAZUWA-PETERS, Margot HURLBERT}

\subsection{1. $\mathrm{CO}_{2}$ classification}

There is a regulatory gap in $\mathrm{CO}_{2}$ classifications. Classifications challenge how we understand and define carbon at different points in the industrial process itself, or at various stages and state (liquid, gas or otherwise). The literature discusses several common classifications. Common classifications of $\mathrm{CO}_{2}$ found in the literature (IEA 2010) include:

1. Hazardous pollutant: In its free state, without CCS processing $\mathrm{CO}_{2}$ that leave the tailpipe of an industrial system, $\mathrm{CO}_{2}$ may be classified as hazardous due to the presence of certain impurities and hydrocarbons that pose some danger to health and wellbeing of people and ecological systems. However, once captured in the CCS process, certain factors that may cause $\mathrm{CO}_{2}$ to be classified as hazardous are its pressure, concentration, and the volume at which it is being stored. Thus, this classification emphasizes the harm that $\mathrm{CO}_{2}$, either in its free state or when captured, can cause.

2. Waste: As a product of industrial processes, without applying CCS technology, $\mathrm{CO}_{2}$ is one of several harmful greenhouse gases that leaves the tailpipe of an industrial system. Its potential to cause harm and the inability for it to be used in any meaningful way causes it to be classified as a waste. Thus, there is a growing emphasis on $\mathrm{CO}_{2}$ utilization rather than just $\mathrm{CO}_{2}$ capture and storage.

3. Commodity: In the context of carbon capture utilization and storage (CCUS) technology, it is difficult not to classify $\mathrm{CO}_{2}$ as a commodity, especially when deployed in EOR or other industrial operations. Here, $\mathrm{CO}_{2}$ becomes an input in an industrial process which transforms it from a waste to a commodity.

Therefore, the line between $\mathrm{CO}_{2}$ being classified as a waste, hazard or dangerous pollutant, or as a commodity lies, for the most part, in whether it is considered an output or an input in an industrial process. Interestingly, no specific reference is made to $\mathrm{CO}_{2}$ classification in all 6 jurisdictions. This would be an area of future regulatory attention. As existing large scale CCS projects in Saskatchewan (Boundary Dam 3) and Texas (Petra Nova) demonstrate, stakeholder involvement is critical to CCS success (Liang, Reiner 2013; Lipponen et al. 2017). Therefore, a common classification for $\mathrm{CO}_{2}$ is critical in creating a clear understanding between multiple stakeholders and ensuring cooperation. 


\subsubsection{CCS capture}

Regulations pertaining to CCS capture include provisions requiring capture, capture permits, approvals, risk assessment and safety requirements of capture sites. Although a few of the regulations discuss reporting, monitoring and evaluation (mostly by identifying roles and responsibilities), the focus was on $\mathrm{CO}_{2}$ emissions limits. In Alberta, the Climate Change and Emissions Management Act and Oil Sands Emissions Limit Act, both provide for greenhouse gas emissions limits or targets. This is also the case in the Canada Reduction of Carbon Dioxide Emissions from Coal-fired Electricity Generation Regulation. Similar standards are also found in Texas and U.S regulations.

\subsubsection{Closure, post-closure and decommissioning}

Once $\mathrm{CO}_{2}$ has been captured and then injected into a storage site, standards for post-injection monitoring, remediation, well plugging and abandonment, and site closure follows (Hart et al. 2012). One major factor limiting CCS deployment is storage capacity. Two common storage options are underground geologic sites and depleted oil and gas wells or reservoirs. The IPCC estimates around 2 trillion tones of worldwide capacity, that is, about 50 times the current emissions levels (GCCSI 2018a). Although only several countries are deemed to have mature storage capacity, the world's highest GHG emitters also have the best or near best storage capacity (GCCSI 2018a).

Regulations making provisions for $\mathrm{CO}_{2}$ storage related activities discuss processes for acquiring storage site closure permits and certificates, set the standards and procedures for monitoring sites, conduct risk assessment, and determine the safety of $\mathrm{CO}_{2}$ storage sites. Another important issue addressed by the regulations is determining criteria for transfer of liability of storage sites, especially after a $\mathrm{CO}_{2}$ storage site is closed.

One significant regulation in this regard is the Alberta Mines and Minerals Act which created a post-closure stewardship fund that helps to cover cost of remediation. An area that requires some regulatory attention would be clarifying the potential for governments to assume more responsibility for storage sites. 


\subsection{4. $\mathrm{CO}_{2}$ injection}

The $\mathrm{CO}_{2}$ injection process and activities are differentiated from those associated with $\mathrm{CO}_{2}$ storage. Injection is primarily associated with the use of captured carbon in EOR activities, which involves the use of depleted oil and gas wells and reservoirs rather than geological formations for storage. The association with oil and gas exploration produces a set of issues that is unique from any other form of storage (in geologic sites). Hence, special regulatory attention to the use of captured carbon in industrial processes such as EOR is warranted. In the study, key provisions found in the regulations include: Monitoring, measurement and verification of $\mathrm{CO}_{2}$ injection; $\mathrm{CO}_{2}$ injection leases and permit/approval process; Health and safety, especially in relation to underground water formations; Pore space ownership and liability; Financial incentives for CO2 use in EOR (more on this later); Standards for $\mathrm{CO}_{2}$ trading; All the jurisdictions studied had at least one reference to one or more of these issues except Canada (Federal regulations).

\subsubsection{Site selection}

Site selection is important to several CCS related activities such as, EOR, $\mathrm{CO}_{2}$ storage, and transportation. The focus here is on procedures for determining the suitability of sites (on-shore or off-shore) in a CCS related activity. In the six jurisdictions studied, only four direct references are made regarding procedures for site selection and all four references are from Texas. The provisions highlight administrative steps regarding monitoring and evaluation of a site's mechanical integrity for various activities such as $\mathrm{CO}_{2}$ injection and storage.

\subsubsection{Storage and long-term liability}

Permanent storage of $\mathrm{CO}_{2}$ implies a long-terms sequestration of captured carbon. The extended time frame involved in $\mathrm{CO}_{2}$ storage creates unique uncertainties as it is impractical to expect the responsible entities to exist for as long 
as the carbon is being stored. Therefore, sub-surface property rights and liability for storage over an extended period may become contentious if not managed by regulations.

The liability question also has a financial and ethical dimension that must be noted. Currently, an unabated emitter of $\mathrm{CO}_{2}$ who fails to develop a CCS facility is free of any liability once the $\mathrm{CO}_{2}$ leaves its facility into the atmosphere. Conversely, without adequate regulatory cover, the liability for captured carbon may become a disincentive for facilities who would first have to bear the cost of deploying CCS technology, and then assume liability in perpetuity for what could be considered an environmental good in capturing the carbon and safely storing them away in underground formations (Bui et al. 2018). This is one situation in which a clear classification of $\mathrm{CO}_{2}$ is required because once captured and stored underground, if classified as a pollutant, waste or hazard, $\mathrm{CO}_{2}$ capture and storage effectively becomes a disposal mechanism. This would have significant administrative and legal implications. Further, classifying $\mathrm{CO}_{2}$ as a hazard, pollutant or waste creates a negative perception. Hence, securing storage sites for $\mathrm{CO}_{2}$ storage may become extremely difficult, if not impossible, because of strong public opposition.

Five jurisdictions in the study (all except Canada (Federal)) had some form of provision for managing long-term liability of stored carbon. Of note is Alberta's approach which has been discussed extensively in the literature. In Alberta, the Crown (Government) recognizes that stakeholders are challenged by the daunting prospect of having to bear responsibility for stored carbon over its lifetime; in perpetuity. Therefore, the Crown assumes liability of storage and takes ownership of storage sites ones a closure certificate is issued to a CCS storage facility operator.

All provisions related to long-term liability in North Dakota are in North Dakota Senate Bill No. 2095, while in Alberta, several pieces of different legislations, including Alberta Mines and Minerals Act and the Oil and Gas Conservation Act, 
capture the issues. Alberta seems to have adjusted existing regulations to manage different aspect of CCS technology.

\subsubsection{Transport}

Transportation is considered of the most mature of all the activities in CCS technology chain (IEA 2013; CIAB 2016). Once captured, $\mathrm{CO}_{2}$ is compressed and then transported typically by pipelines, but shipping is also a feasible option. Important issues under transport include pipeline ownership (common ownership to avoid monopolies in $\mathrm{CO}_{2}$ pipeline infrastructure), cost of developing pipeline infrastructure/network, common carrier issues or hub-transport agreements, the safety requirements for different modes of transport, measurement, verification and reporting needed to obtain permits, site selection, and approvals for $\mathrm{CO}_{2}$ transportation. $\mathrm{CO}_{2}$ classification becomes relevant once more as it informs acceptable technical standards for pipes used or any other means adopted for transportation. Further, accelerating $\mathrm{CCS}$ deployment requires adequate $\mathrm{CO}_{2}$ transport infrastructure to provide access to jurisdictions with adequate or sound geologic storage systems. This is one reason why the lack of streamlined regulatory systems for $\mathrm{CO}_{2}$ classification is critical.

All but Canada (Federal regulation) have some provision for one or more of the issues. However, it is interesting that most of the regulations discuss liability for abandoned pipelines and they stipulate a requirement to carry $\mathrm{CO}_{2}$ without discrimination (common carrier issues).

\subsection{Financial issues}

CCS technology, as with all innovative new technologies, is not cheap. The cost of CCS has been a major obstacle to development over the last two decades (World Resource Institute 2011; Napp et al. 2014; Budinis et al. 2018). That said, lessons can be learned from more mature technologies, especially renewable technologies 
such as wind and solar which were, not long ago, considered too expensive as well. Managing the cost of CCS can take any one or a combination of these three approaches:

1. Reduce the cost of developing a CCS project upfront. As much as $67 \%$ reduction in cost can be achieved for second-generation CCS designs under certain circumstances (CCS Knowledge Centre 2018).

2. Increase the economic value of CCS technology. This could involve developing innovative ways of using $\mathrm{CO}_{2}$ beyond EOR; emphasizing CCUS (carbon capture, utilization and storage) rather than just CCS (carbon capture and storage) and leveraging private investments in CCS through initial public support and funding.

3. Creating a market-based system for trading $\mathrm{CO}_{2}$ as a commodity to solidify the role of private capital and investment in CCS technology and further unlock the financial potentials in CCS technology.

In the literature, mechanisms for supporting the economics of CCS range from financial contributions by governments to the development of a market-based system. The most common mechanisms are highlighted in Figure 4 (below) which shows a distribution of regulatory provisions for various mechanisms meant to support CCS development. Based on the number of references to financial issues in the regulations, it can be said that regulatory provisions in the area of CCS finance are, at best, still growing when compared to what is obtainable for issues of technical relevance to CCS technology. 


\section{Figure 6. Distribution of references to financial issues in regulations}

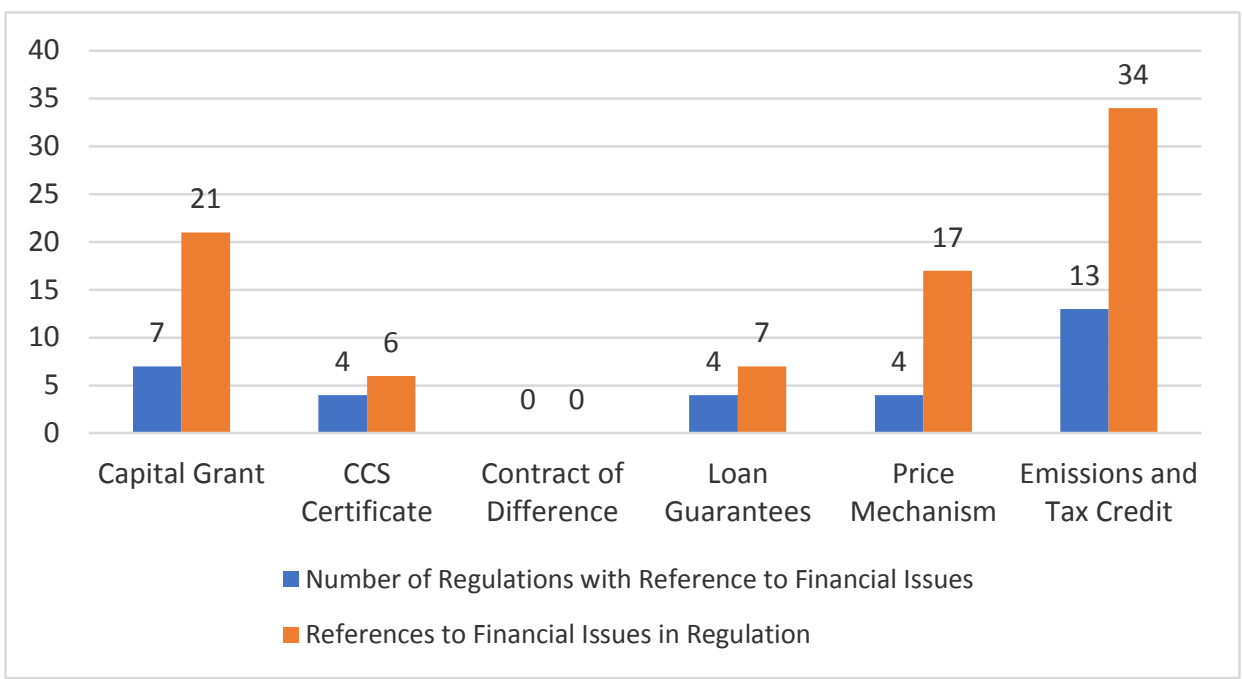

Source: Compiled by the authors from NVivo analysis.

Table 2. Mechanisms for financial support in early stage CCS development

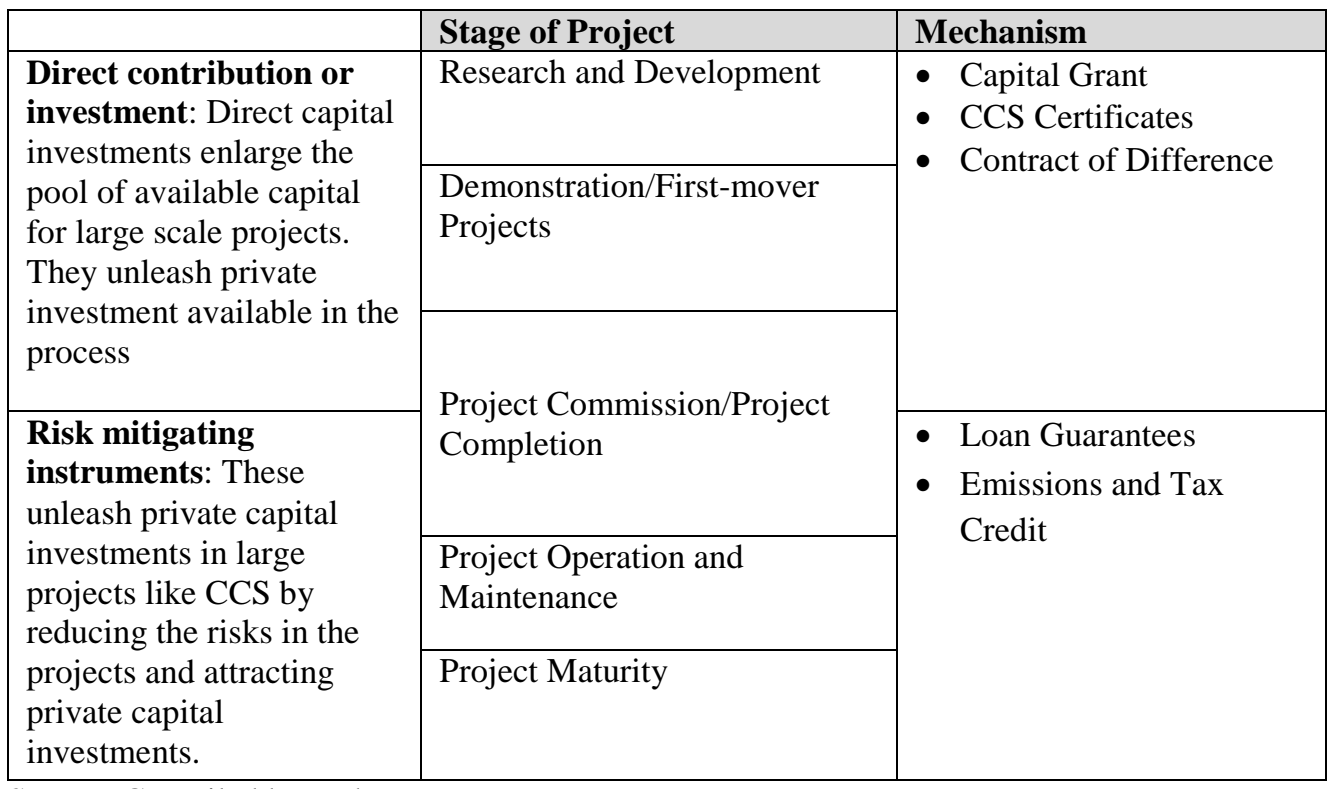

Source: Compiled by authors. 
Governments play a big role in reducing the risk in new technologies in their early stages, allowing private capital investments to flourish. This can be done through a variety of ways as shown in Table 2 . These mechanisms are flexible and can be applied at different stages of a CCS project. Where possible, several mechanisms may be adopted and are discussed below (ADB et al. 2012).

\subsubsection{Capital grants}

Capital grants are direct financial supports provided by government in furthering a CCS project. Although regarded as useful in breaking down inertia due to uncertainties and risks in first-mover or demonstration projects, about $77 \%$ of total investment in CCS projects since 2005 have come from private interests (Anbumozhi et al. 2018). Ogihara (2018) asserts government investment in CCS facilities hurts the development of CCS technology.

Four jurisdictions (Alberta, Saskatchewan, Texas and the U.S) had provisions for government's financial support of CCS projects through capital grants. For example, in Saskatchewan, a combination of direct capital grants from both the provincial and federal governments provided liquid cash which SaskPower (the province's power generation and distribution company and owner of the CCS facility) used for the CCS project.

\subsubsection{CCS certificate}

A CCS certificate is a 'quantity instruments' that sets a baseline target for $\mathrm{CO}_{2}$ capture. Solar and Wind technologies have benefited from certificates surrounding targeting quantity of GHG emissions reduced. When adapted for CCS technology, the objective can extend beyond a measurement of clean energy output by a CCS facility to include such things as amount of $\mathrm{CO}_{2}$ stored. In the six jurisdictions studied, only in Canada (Federal), North Dakota and Texas are there regulatory provisions that highlight quantity measures for CCS facilities

\subsubsection{Contracts of difference}

Contracts of Difference (CfD) are important financial tools for signaling the potential for CCS technology and renewable technologies such as wind and solar to 
co-exist. The use of CfDs is based on two major premises: (1) CCS technology is the bridge between a fossil fuel based system and a renewables based system, and (2) over the longer term, as the use of renewables increases and conventional coal plants or those with CCS technology lose their share of generating capacity, the CfDs become a primary means of guaranteeing that these facilities do not become stranded assets and continue to provide base load generation.

The typical life cycle of a CCS project is at least 30 years. Thus, to attract the necessary investment, guarantees against potential losses through mechanisms such as CfDs are critical (Kapetaki et al. 2017; Sartor, Bataille 2019). This is clearly an area where some regulatory attention is needed as no jurisdiction in this study had direct provisions for developing or administering a CfD.

\subsubsection{Emissions and tax credits}

All six jurisdictions had references to a system of incentivizing CCS activities through credits, rebates or by other means although the level and strength of the credit system vary by jurisdiction. Emissions and tax credits work in nearly the same way as CCS certificates, except, emissions reduction is the major outcome being measured and rewarded through a tax credit, whereas in CCS certificates, other outcomes like power production (using clean or low carbon technology) may also be measured. The development of an emissions tax credit system can be a first step toward developing a carbon market.

Unlike capital grants that are upfront or may come at specific points in the life of a CCS project, emissions tax credits are ongoing and can cover some of the operational costs associated with a CSS facility. Since CCS technology is a chain of linked technologies, the credits could be issued for achieving different targets along the CCS chain. In the Saskatchewan case, due to the use of captured carbon in EOR activities, credits are used to reduce oil and gas royalty payments.

Emission credits may also be in the form of direct payments where transfers are made per ton of $\mathrm{CO}_{2}$ captured, stored or utilized. A good example of this is the recent amendments made to section 45Q of the U.S Internal Revenue Code which allows substantial revisions of payments made for capturing, storing or utilizing $\mathrm{CO}_{2}$. 


\subsubsection{Loan guarantees}

North Dakota, Saskatchewan, Texas and the U.S federal level offer loan guarantees to banks and financial institutions funding a CCS project. The extension of a loan guarantee for CCS projects may never result in financial obligations, but serves as a critical buffer reducing financial risk exposure and uncertainty for financial institutions funding CCS projects. However, this study shows that it is not clear how such system works in cases where foreign, multinational or multilateral financing institutions are involved in financing a project. In the context of Article 6 of the Paris Agreement, this is a fundamental regulatory issue for the immediate future of CCS technology.

Loan guarantees thus function as a catalyst driving private investment in CCS projects as it did in the renewable energy sector (Brown, Jacobs 2011; IEA 2012). Unfortunately, in applying loan guarantees for CCS projects, the conditions have been notably stringent (Anbumozhi et al. 2018). Thus, there is a sense that more private capital could be leveraged if administrative burdens, including those in the application process, are eased (Jacobs, Craig 2017).

\subsubsection{Price mechanism}

The most common price mechanisms supporting CCS project development are the cap-and-trade and carbon tax. In the case of the carbon tax, its purpose is to make carbon intensive activities more expensive, and drive power generation towards a low carbon system. On the other hand, cap-and-trade follows a market model were a highly developed system of emissions trading or market is developed and emissions credits can be traded between parties. While both are touted as important tools for accelerating the deployment of innovative clean energy technologies like CCS, serious political-economy questions which have remained unresolved have hampered their use in many parts of the world.

Currently, more than sixty national and subnational pricing mechanisms exist around the world. In Canada, the Federal government has imposed a national carbon price which began by January of 2019 (Government of Canada 2016). However, this has been opposed by a number of provinces (CBC News 2019; Ljunggren 2019). 
Generally, the application of a price mechanism varies widely because the pricing mechanism bridges quantity-based and price-based initiatives. Thus, different jurisdictions decide how far they will go. In Saskatchewan for example, the province set an emissions limit without a price system for trading carbon. Other jurisdictions in this study with regulatory provisions that refer to one or more aspects of carbon pricing include Alberta, Texas, and Canada. In Alberta, there is a price on carbon in the form of a carbon levy which is collected in a central fund used for climate change initiatives. In Texas, such payment may be charged for $\mathrm{CO}_{2}$ storage.

\subsection{Information}

Public perception of innovative technologies can be an obstacle to accelerated deployment if it is negative (L'Orange Seigo et al. 2014; van Alphen et al. 2007; Wallquist et al. 2010; Bradbury et al. 2008; Bui et al. 2018). This regulatory area has received the least number of regulations. In the literature, public perception is often discussed in its context as a 'social good'; the Global CCS Institute argues that considering public perception of CCS technology as a 'non-commercial' issue is a mistake (GCCSI 2009). Public perception of CCS is difficult to manage because people's perception may not be a function of the technology itself (a combination of the technical and economic factor) as it may be a function of where they live, their politics, their knowledge of the technology in relation to the overall energy system, and their connection to fossil fuel industry (L'Orange Seigo et al. 2014; van Alphen et al. 2007; Wallquist et al. 2010; Bradbury et al. 2008; Bui et al. 2018).

To resolve challenges arising from negative public perception, public engagement has become a staple for major developmental projects in most part of the world and has been considered an opportunity to enlarge the community of stakeholders involved in a project, to co-create and co-own the project, and to develop lasting relationships needed to achieve the desired outcomes (Lash 2010). Public engagement strategies adopted must always include opportunities for all parties to adjust their goals and preferences in relation to the project (Breukers, Upham 2015). In that sense then, the goal should never be overcoming a barrier to deployment, instead, it should be expanding the stakeholder pool to include locals 
who will see value (both economic and social) in the project and become active advocates and participants in the development and sustainability of the project (GCCSI 2014).

CCS technology developers engage local public in different ways. In fact, regulations in Alberta, Canada (Federal), North Dakota, Saskatchewan and the U.S all have provisions that acknowledge the need to involve local publics in the decision-making processes that lead to siting of a CCS facility. Some of these regulations include dispute resolution procedure which requires members of the community to be part of an advisory committee to the government. Others have included benefit sharing as a way to galvanize support of local publics, particularly those within the immediate geographical location of a CCS facility. Benefit sharing schemes are meant to demonstrate the social value of a CCS facility for the community that hosts its, rather than pay to gain access to the community or their acceptance (ter Mors et al. 2014).

In a 2013 study, ERM (a global consulting company) and the $\mathrm{CO}_{2}$ Capture Project (CPP), (a consortium of CCS technology stakeholders) conducted a study that revealed that benefit sharing can be achieved by:

1. Revenue sharing, especially when $\mathrm{CO}_{2}$ is utilized for EOR or other industrial purposes

2. Direct investment in the community through investment in a local trust fund or other local initiatives

3. Community investment in $\mathrm{CO}_{2}$ storage projects (perhaps through some sort of local content provision)

4. Shared commitment by government/developer/community in social management programs through education programs, on-site visits and learning centers

Still, the authors warn that benefits sharing should not be perceived as a "«silver bullet» when it comes to local acceptance" (ERM, CPP 2013), but be incorporated into a wider scheme that develops public trust in the projects by allowing the public to participate in taking ownership of the project (Bonham et al. 2014). In this study, it was found that the U.S Energy Independence and Security Act privileges projects that ensures local content in CCS development projects when making deciding 
between competing projects. No reference to issues related to benefit sharing was found in all other 5 jurisdictions.

\section{Concluding remarks}

Trends in energy consumption show that fossil fuel will continue to be consumed into the future and that emissions, particularly from developing countries, is still increasing which means that CCS will be needed at least in the short term (IEA 2018a; GCCSI 2017, 2018b). A growing appetite for $\mathrm{CO}_{2}$ utilization fuels innovation in CCS technology and learning from existing CCS projects is driving down capital cost projections for future builds (International CCS Knowledge Centre 2018). However, policies are needed to support CCS project development, but policies don't exist in a regulatory vacuum. Hence, more attention should be paid to development a regulatory regime or structure that supports CCS technology development.

Several gaps were identified in regulatory regimes. First, advancing public acceptance may benefit from socio-economic policies specifically relating to public engagement, providing information, and advancing societal benefits sharing (revenue sharing, investment in the community, shared social management). These regulations were found to be lacking. Second, although financial instruments were the second most predominant form of regulation, contracts for differences were missing as well as loan guarantees at the international, multinational and multilateral levels. Third, although many technical regulations exist there is a regulatory gap in the classification of $\mathrm{CO}_{2}$. The literature describes it as a hazardous pollutant, waste or a commodity. Reconciling this would advance understanding of CCS. Lastly, not all jurisdictions have post CCS closure, stewardship and liability provisions.

This article provides a portfolio of regulations advancing CCS including technical regulations, pore space ownership, monitoring, enforcement and verification of $\mathrm{CO}_{2}$ injection. Regulations focusing primarily on technical aspects of CCS including capture, transport, and liability predominate while there are less regulatory provisions for the financial aspects of CCS technology as well as public 
engagement and support. While capital grants and emission and tax credits are the predominant financial regulations, streamlining cap and trade provisions across borders warrants more attention.

Many scenarios to maintain global warming below 2 degrees Celsius require combinations of new technology including CCS. The focus on CCS cost as a barrier to deployment overshadows the needs for regulatory support as a means of reducing uncertainties and de-risking CCS investments.

\section{References}

ADB, The World Bank, World Resource Institute (2012), funding carbon capture and storage in developing countries, Global CCS Institute, Melbourne, http://decarboni.se/sites/default/files/publications/37906/fundingccsindevelopingcountriesfin al.pdf [10.12.2018]

Anbumozhi V., Kalirajan K., Kimura F. (eds.) (2018), Financing for low-carbon energy transition. Unlocking the potential of private capital, Springer, Singapore.

Blanford G., Merrick J., Richels R., Rose S. (2014), Trade-offs between mitigation costs and temperature change, "Climate Change", vol. 123 no. 3-4, pp. 527-541.

Bonham S., Chrysostomidis I., Crombie M., Burt D., van Greco C., Lee A. (2014), Local community benefit sharing mechanisms for CCS projects, "Energy Procedia", vol. 63, pp. 8177-8184.

Bradbury J., Ray I., Peterson T., Wade S., Wong-Parodi G., Feldpausch A. (2009), The role of social factors in shaping public perceptions of CCS. Results of multi-state focus group interviews in the U.S., "Energy Procedia", vol. 1 no. 1, pp. 4665-4672.

Brown J., Jacobs M. (2011), Leveraging private investment: the role of public sector climate finance, Overseas Development Institute, London, https://www.odi.org/sites/odi.org.uk/files/odi-assets/publications-opinion-files/7082.pdf [10.12.2018].

Breukers S., Upham P. (2013), Organizational aspects of public engagement in European energy infrastructure planning. The case of early-stage CCS projects, "Journal of Environmental Planning and Management", vol. 58 no. 2, pp. 252-269.

Budinis S., Krevor S., MacDowell N., Brandon N., Hawkes A. (2018), An assessment of CCS costs, barriers and potential, "Energy Strategy Review", vol. 22, pp. 61-81. 


\section{Mac OSAZUWA-PETERS, Margot HURLBERT}

Bui M., Adjiman C., Bardow A., Anthony E., Boston A., Brown S., ..., Dowell N. (2018), Carbon capture and storage (CCS). The way forward, "Energy \& Environmental Science", vol. 11 no. 5, pp. 1062-1176.

CBC News (2019), Manitoba premier stands by federal carbon tax opposition, but says he wants to work with Ottawa, CBC News, https:/www.cbc.ca/news/canada/manitoba/brianpallister-carbon-tax-opposition-election-1.5331216 [01.01.2020].

CIAB (Coal Industry Advisory Board) (2016), An international commitment to CCS. Policies and incentives to enable a low-carbon energy future, International Energy Agency, Paris, https://www.iea.org/ciab/papers/CIAB_Report_CCSReport.pdf [10.12.2018].

Choptiany J., Pelot R., Sherren K. (2014), An interdisciplinary perspective on carbon capture and storage assessment methods, "Journal of Industrial Ecology", vol. 18 no. 3, pp. 445-458.

de Coninck H., Benson S.M. (2014), Carbon dioxide capture and storage: issues and prospects, “Annual Review of Environment and Resources”, vol. 39, pp. 243-270.

den Elzen M., Lucas P., van Vuuren D. (2008), Regional abatement action and costs under allocation schemes for emission allowances for achieving low $\mathrm{CO} 2$ equivalent concentrations, "Climatic Change", vol. 90 no. 3, pp. 243-268.

Edelenbosch O.Y., McCollum D., van Vuuren D., Bertram C., Carrara S., Daly H., ..., Sano F. (2016), Decomposing passenger transport futures. Comparing results of global integrated assessment models, "Transportation Research, Part D: Transport and Environment", vol. 55, pp. 281-293.

ERM, CPP (2013), Benefits sharing and options for $\mathrm{CO}_{2}$ storage projects, Global CCS Institute, Melbourne, at: http://hub.globalccsinstitute.com/insights/benefits-sharing-andoptions-co2-storage-projects-cop19-side-event [10.12.2018].

GCCSI (Global CCS Institute) (2009), Strategic analysis of the global status of carbon capture and storage. Report 5, The Global CCS Institute, Melbourne, http://decarboni.se/sites/default/files/publications/5751/report-5-synthesis-report.pdf [10.12.2018].

GCCSI (2014), The global status of CCS: 2014, The Global CCS Institute, Melbourne, https://www.globalccsinstitute.com/resources/global-status-report/previous-reports/ [10.12.2018].

GCCSI (2017), The global status of CCS: 2017, The Global CCS Institute, Melbourne, https://www.globalccsinstitute.com/wp-content/uploads/2018/12/2017-Global-StatusReport.pdf [10.12.2018]. 
GCCSI (2018a), Is the world ready for carbon capture and storage? Global CCS Institute: Insights. The Global CCS Institute, Melbourne, https://www.globalccsinstitute.com/newsmedia/insights/is-the-world-ready-for-carbon-capture-and-storage/ [10.12.2018].

GCCSI (2018b), The global status of CCS: 2018, The Global CCS Institute, Melbourne, https://www.globalccsinstitute.com/resources/global-status-report/ [10.12.2018].

Government of Canada (2016), Pan-Canadian Framework on Clean Growth and Climate Change, Ministry of Environment and Natural Resources, https://www.canada.ca/en/services/environment/weather/climatechange/pan-canadianframework/climate-change-plan.html [10.12.2018].

Hart C., Tomski P., Coddington K. (2012), permitting issues related to carbon capture and storage for coal-based power plant projects in developing APEC economies, Asia-Pacific Economic Development (APEC), Singapore, https://www.apec.org/Publications/2012/09/Permitting-Issues-Related-to-Carbon-Captureand-Storage-for-CoalBased-Power-Plant-Projects-in-Develo [10.12.2018].

Howlett M. (2009), Governance modes, policy regimes and operational plans. A multi-level nested model of policy instrument choice and policy design, "Policy Science", vol. 42 no. 1, pp. 73-89.

Howlett M. (2019), Designing public policies. Principles and instruments, 2nd ed., Routledge, London - New York.

IEA (International Energy Agency) (2010), Carbon capture and storage. Model regulatory framework, IEA, Paris, https://www.iea.org/publications/freepublications/publication/model_framework.pdf [10.12.2018].

IEA (2012), A policy strategy for carbon capture and storage, IEA, Paris, https://www.iea.org/publications/freepublications/publication/policy_strategy_for_ccs.pdf [10.12.2018].

IEA (2013), Technology development roadmap: carbon capture and storage, IEA, Paris, https://www.iea.org/publications/freepublications/publication/TechnologyRoadmapCarbonC aptureandStorage.pdf [10.12.2018].

IEA (2017), CCS deployment in the context of regional developments in meeting long-term climate change objectives, IEA Greenhouse Gas R\&D Program: 2017 Technical Report, IEA, Paris, https://ieaghg.org/publications/technical-reports [10.12.2018].

IEA (2018a), World Energy Outlook, IEA, Paris, https://www.iea.org/weo2018/ [10.12.2018]. 


\section{Mac OSAZUWA-PETERS, Margot HURLBERT}

IEA (2018b), Global energy \& $\mathrm{CO}_{2}$ status report. The latest trends in energy and emissions in 2017, IEA, Paris, https://www.iea.org/geco/ [10.12.2018].

IEA (2019), Transforming industry through CCUS, IEA, Paris, https://www.iea.org/reports/transforming-industry-through-ccus [01.01.2020].

International CCS Knowledge Centre (2018), The Shand CCS feasibility study public report, International CCS Knowledge Centre, Saskatchewan, https://ccsknowledge.com/pub/documents/publications/.Shand\%20CCS\%20Feasibility\%20S tudy\%20Public\%20Report_NOV2018.pdf [10.12.2018].

International Risk Governance Council (IRGC) (2008), Regulation of carbon capture and storage: policy brief, IRGC, Lausanne, https://irgc.org/issues/carbon-capture-andstorage/regulation-of-carbon-capture-and-geological-storage/ [10.12.2018].

Jacobs W., Craig M. (2017), Legal pathways to widespread carbon capture and sequestration, Environmental Law Institute, Washington DC, https://www.eli.org/sites/default/files/elr/featuredarticles/47.11022.pdf [10.12.2018].

Kanudia A., Labriet M., Loulou R. (2014), Effectiveness and efficiency of climate change mitigation in a technologically uncertain world, "Climatic Change", vol. 123 no. 3-4, pp. 543-558.

Kapetaki Z., Hetland J., LeGuenan T., Mikunda T., Scowcroft J. (2017), Highlights and lessons from the EU CCS demonstration project network, "Energy Procedia", vol. 114, pp. $5562-5569$.

Kemper, J. (2015), Biomass and carbon dioxide capture and storage: a review, "International Journal of Greenhouse Gas Control”, vol. 40, pp. 401-430.

Koelbl B.S., van den Broek M.A., Faaij A.P., van Vuuren D.P. (2014), Uncertainty in carbon capture and storage (CCS) deployment projections. A cross-model comparison exercise, "Climatic Change", vol. 123 no. 3-4, pp. 461-476.

L'Orange Seigo S., Dohle S., Siegrista M. (2014), Public perception of carbon capture and storage (CCS): a review, "Renewable and Sustainable Energy Reviews", vol. 38, pp. 848863.

Lash J. (2010), Engaging communities in carbon capture and storage projects, World Resource Institute, Washington DC, https://www.wri.org/blog/2010/11/engagingcommunities-carbon-capture-and-storage-projects [10.12.2018].

Liang X., Reiner D. (2013), The evolution of stakeholder perceptions of deploying CCS technologies in China. Survey results from three stakeholder consultations in 2006, 2009 and 2012, "Energy Procedia", vol. 37, pp. 7361-7368. 
Lipponen J., McCulloch S., Keeling S., Stanley T., Berghout N., Berly T. (2017), The politics of large-scale CCS deployment, "Energy Procedia”, vol. 114, pp. 7581-7595.

Ljunggren D. (2019), Canadian provinces vow to resist Trudeau's landmark carbon tax, Reuters, https://www.reuters.com/article/us-canada-politics-environment/canadianprovinces-vow-to-resist-trudeaus-landmark-carbon-tax-idUSKCN1RD2SE [01.01.2020].

Markusson N., Kern F., Watson J., Arapostathis S., Chalmers H., Ghaleigh N., ..., Russell S. (2012), A socio-technical framework for assessing the viability of carbon capture and storage technology, "Technological Forecasting \& Social Change", vol. 79 no. 5, pp. 903-908.

Napp T., Sum K.S., Hills T., Fennell P. (2014), Attitudes and barriers to deployment of CCS from industrial sources in the UK, UK Grantham Institute for Climate Change, London, https://www.imperial.ac.uk/media/imperial-college/grantham-

institute/public/publications/institute-reports-and-analytical-notes/Attitudes-and-Barriers-toCCS---GR6.pdf [01.01.2020].

Ogihara A. (2018), Mapping the necessary policy instruments to unlock the potentials of private finance for carbon capture and storage technologies, in: Financing for low-carbon energy transition. Unlocking the potential of private capital, Anbumozhi V., Kalirajan K., Kimura F. (eds.), Springer, Singapore.

Popp A., Rose S., Calvin K., van Vuuren D., Dietrich J.P., Wise M., ..., Kriegler E. (2014), Land-use transition for bioenergy and climate stabilization. Model comparison of drivers, impacts and interactions with other land use based mitigation options, "Climate Change", vol. 123 no. $3-4$, pp. $495-509$.

Popp A., Calvin K., Fujimori S., Havlik P., Humpenoder F., Stehfest E., .., van Vuuren D. (2017), Land-use futures in the shared socio-economic pathways, "Global Environmental Change", vol. 42, pp. 331-345.

Riahi K., van Vuuren D., Kriegler E., Edmonds J., O’Neil B., Fujimori S., ..., Tavoni M. (2017), The shared socioeconomic pathways and their energy, land use, and greenhouse gas emissions implications. An overview, "Global Environmental Change", vol. 42, pp. 153-168.

Sanchez D., Kammen D. (2016), A commercialization strategy for carbon-negative energy. "Nature Energy", vol. 1.

Sartor O., Bataille C. (2019), Decarbonising basic materials in Europe. How carbon contracts-for-difference could help bring breakthrough technologies to market, IDDRI Study $\mathrm{N}^{\circ} 06 / 19$,

Paris, https://www.iddri.org/sites/default/files/PDF/Publications/Catalogue\%20Iddri/Etude/201910 -ST0619-CCfDs_0.pdf [01.01.2020].

Sawyer D., Harding R., Pozlott C., Dickey P. (2008), Carbon capture and storage. The environmental and economic case and challenges, Pembina Institute, International Institute 


\section{Mac OSAZUWA-PETERS, Margot HURLBERT}

for Sustainable Energy (IISD), Institute for Sustainable Energy, Environment and Economy, Alberta, https://www.pembina.org/reports/ccs-discuss-environment-economic-all.pdf [01.01.2020].

Scott M.J., Edmonds J.A., Mahasenan N., Roop J.M., Brunello A.L., Haites E.F. (2004), International emission trading and the cost of greenhouse gas emissions mitigation and sequestration, "Climatic Change", vol. 64 no. 3, pp. 257-287.

Tavoni M., De Cian E., Luderer G., Steckel J.C., Waisman H. (2012), The value of technology and of its evolution towards a low carbon economy, "Climatic Change", vol. 114 no. 1 , pp. 39-57.

ter Mors E., Terwel B., Zaal M. (2014), Can monetary compensation ease the siting of CCS projects?, "Energy Procedia", vol. 63, pp. 7113-7115.

US Department of Energy (2016), Carbon capture, utilization, and storage. Climate change, economic competitiveness, and energy security, US Department of Energy, Washington DC, https://www.energy.gov/sites/prod/files/2017/01/f34/Carbon\%20Capture\%2C\%20Utilization $\% 2 \mathrm{C} \% 20$ and $\% 20$ Storage--

Climate\%20Change \%2C\%20Economic\%20Competitiveness $\% 2 \mathrm{C} \% 20$ and $\% 20$ Energy $\% 20 \mathrm{Se}$ curity_0.pdf [01.01.2020].

van Alphen K., tot Voorst Q.V.V., Hekkert M.P., Smits R.E. (2007), Societal acceptance of carbon capture and storage technologies, "Energy Policy", vol. 35 no. 8, pp. 4368-4380.

van Vuuren D.P., van Soest H., Riahi K., Clarke L., Krey V., Kriegler E., ..., Tavoni M. (2016), Carbon budgets and energy transition pathways, "Environmental Research Letters", vol. 11 no. 7 , pp. 1-13.

Wallquist L. Visschers V., Siegrist M. (2010), Impact of knowledge and misconceptions on benefit and risk perception of CCS, "Environmental Science and Technology", vol. 44 no. 17, pp. 6557-6562.

World Resource Institute (2011), Who pays for carbon dioxide capture and storage (CCS) demonstrations in developing countries?, World Resource Institute, Washington DC, https://www.wri.org/blog/2011/04/who-pays-carbon-dioxide-capture-and-storage-ccsdemonstrations-developing-countries [12.02.2020]. 


\section{APPENDIX 1. Coding guide - CCS regulations project}

This document describes what constitutes each case-node in this project.

This project has 49 regulations as its total universe. Specific provisions within those regulations are coded to each case-node as described below.

\begin{tabular}{|c|c|c|c|c|c|c|c|}
\hline & A : Capture & $\begin{array}{l}\text { B : Closure, } \\
\text { Post-closure } \\
\text { and } \\
\text { Decommissi } \\
\text { on }\end{array}$ & $\begin{array}{l}\mathrm{C}: \mathrm{CO}_{2} \\
\text { Classificatio } \\
\quad \mathrm{n}\end{array}$ & $\begin{array}{l}\mathrm{D}: \mathrm{CO}_{2} \\
\text { Injection }\end{array}$ & $\begin{array}{l}\text { E : Site } \\
\text { selection }\end{array}$ & $\begin{array}{l}\text { F : Storage } \\
\text { and Long- } \\
\text { term } \\
\text { Liabilities }\end{array}$ & $\begin{array}{l}\text { G : } \\
\text { Transp } \\
\text { ort }\end{array}$ \\
\hline $\begin{array}{l}1: \text { Alberta CARBON CAPTURE AND } \\
\text { STORAGE ACT + Amendment Regulation }\end{array}$ & No & No & No & No & No & No & No \\
\hline $\begin{array}{l}2: \text { Alberta CARBON SEQUESTRATION } \\
\text { TENURE REGULATION }\end{array}$ & No & Yes & No & Yes & No & No & No \\
\hline $\begin{array}{l}3: \text { Alberta CLIMATE CHANGE AND } \\
\text { EMISSIONS MANAGEMENT ACT }\end{array}$ & Yes & No & No & No & No & No & No \\
\hline 4 : Alberta CLIMATE LEADERSHIP ACT & No & No & No & No & No & No & No \\
\hline $\begin{array}{l}5: \text { Alberta ENVIRONMENTAL } \\
\text { PROTECTION AND ENHANCEMENT } \\
\text { ACT }\end{array}$ & Yes & Yes & No & Yes & No & No & Yes \\
\hline $\begin{array}{l}\text { 6: Alberta METALLIC AND } \\
\text { INDUSTRIAL MINERALS TENURE } \\
\text { REGULATION }\end{array}$ & No & No & No & No & No & No & No \\
\hline 7: Alberta Mines and Minerals Act & No & Yes & No & Yes & No & Yes & No \\
\hline $\begin{array}{l}\text { 8: Alberta OIL AND GAS } \\
\text { CONSERVATION ACT }\end{array}$ & No & Yes & No & Yes & No & Yes & Yes \\
\hline $\begin{array}{l}\text { 9: Alberta OIL SANDS EMISSIONS } \\
\text { LIMIT ACT }\end{array}$ & Yes & No & No & No & No & No & No \\
\hline $10:$ Alberta Pipeline Act & No & No & No & No & No & No & Yes \\
\hline $\begin{array}{l}11: \text { Alberta RESPONSIBLE ENERGY } \\
\text { DEVELOPMENT ACT }\end{array}$ & No & No & No & No & No & No & No \\
\hline $\begin{array}{l}\text { 12: Alberta Specified Gas Emitters } \\
\text { Regulation }\end{array}$ & Yes & No & No & No & No & Yes & No \\
\hline $\begin{array}{l}\text { 13: Alberta SPECIFIED GAS } \\
\text { REPORTING REGULATION }\end{array}$ & Yes & No & No & Yes & No & No & No \\
\hline 14 : Alberta Surface Rights Act & No & No & No & Yes & No & No & No \\
\hline 15 : Alberta WATER ACT & No & No & No & Yes & No & No & No \\
\hline 16 : Canada Emission Incentive Agency Act & No & No & No & No & No & No & No \\
\hline $\begin{array}{l}17 \text { : Canada Kyoto Protocol Implementation } \\
\text { Act }\end{array}$ & Yes & No & No & No & No & No & No \\
\hline 18: Canada Oil and Gas Operations Act & No & No & No & No & No & No & No \\
\hline $\begin{array}{l}19: \text { Canada Reduction of Carbon Dioxide } \\
\text { Emissions from Coal-fired Generation of } \\
\text { Electricity Regulation }\end{array}$ & Yes & No & No & No & No & No & No \\
\hline $\begin{array}{l}20 \text { : Canadian Environmental Assessment } \\
\text { Act }\end{array}$ & Yes & No & No & No & No & No & No \\
\hline 21 : North Dakota Century Code 49-19- 01 & No & No & No & No & No & No & Yes \\
\hline 22 : North Dakota Century Code $57-39.2$ & No & No & No & No & No & No & No \\
\hline 23 : North Dakota Century Code 57 - 60 & No & No & No & No & No & No & No \\
\hline
\end{tabular}


Mac OSAZUWA-PETERS, Margot HURLBERT

\begin{tabular}{|c|c|c|c|c|c|c|c|}
\hline 24 : North Dakota Century Code 57-51.1 & No & No & No & No & No & No & No \\
\hline $\begin{array}{l}25 \text { : North Dakota GEOLOGIC STORAGE } \\
\text { OF CARBON DIOXIDE Article 43-05 }\end{array}$ & No & No & No & Yes & No & Yes & No \\
\hline $\begin{array}{l}26 \text { : North Dakota SENATE BILL NO. } \\
2034 \text { Sub } 5 \text { + Amendment }\end{array}$ & No & No & No & Yes & No & No & No \\
\hline $\begin{array}{l}27 \text { : North Dakota SENATE BILL NO. } \\
2095\end{array}$ & Yes & No & No & Yes & No & Yes & No \\
\hline $\begin{array}{l}28 \text { : North Dakota SENATE BILL NO. } \\
2139\end{array}$ & No & No & No & No & No & No & No \\
\hline 29: Saskatchewan Crown Minerals Act & No & No & No & No & No & No & No \\
\hline $\begin{array}{l}30 \text { : Saskatchewan Environmental } \\
\text { Management and Protection Act }\end{array}$ & Yes & No & No & Yes & No & Yes & No \\
\hline $\begin{array}{l}31 \text { : Saskatchewan Management and } \\
\text { Reduction of Greenhouse Gases Act }\end{array}$ & Yes & No & No & No & No & No & No \\
\hline $\begin{array}{l}32 \text { : Saskatchewan OIL AND GAS } \\
\text { CONSERVATION REGULATIONS }\end{array}$ & Yes & No & No & Yes & No & No & No \\
\hline 33 : Saskatchewan Pipeline Act & No & No & No & No & No & No & Yes \\
\hline $\begin{array}{l}34 \text { : Saskatchewan -The Crown Oil and Gas } \\
\text { Royalty Regulation }\end{array}$ & No & No & No & No & No & No & No \\
\hline $\begin{array}{l}35 \text { : Saskatchewan The Environmental } \\
\text { Assessment Act }\end{array}$ & No & No & No & No & No & No & No \\
\hline 36 : Texas House Bill HB 149 & Yes & No & No & Yes & No & Yes & No \\
\hline 37 : Texas House Bill HB 1796 & Yes & No & No & No & Yes & Yes & Yes \\
\hline 38 : Texas House Bill HB 469 & No & No & No & No & No & Yes & No \\
\hline 39: Texas House Bill SB 1387 & No & Yes & No & Yes & Yes & Yes & No \\
\hline $\begin{array}{l}40 \text { : U.S Accountable Pipeline Safety and } \\
\text { Partnership Act of } 1996\end{array}$ & No & No & No & No & No & No & Yes \\
\hline $\begin{array}{l}41 \text { : U.S Carbon Pollution Emission } \\
\text { Guidelines for Existing Stationary Sources- } \\
\text { Electric Utility Generating Units } 80 \text { FR } 205\end{array}$ & Yes & No & No & No & No & No & No \\
\hline 42 : U.S Clean Air Act & Yes & No & No & No & No & No & No \\
\hline $\begin{array}{l}43 \text { : U.S Energy Improvement and } \\
\text { Extension Act House Resolution H.R } 6049\end{array}$ & Yes & No & No & No & No & No & No \\
\hline $\begin{array}{l}44 \text { : U.S ENERGY IMPROVEMENT AND } \\
\text { EXTENSION ACT OF } 2008+45 Q \\
\text { Amendment }\end{array}$ & No & No & No & No & No & Yes & No \\
\hline $\begin{array}{l}45: \text { U.S Energy Independence and Security } \\
\text { Act }\end{array}$ & Yes & No & No & Yes & No & Yes & No \\
\hline 46 : U.S ENERGY POLICY ACT OF 2005 & Yes & No & No & No & No & No & No \\
\hline 47 : U.S Energy Tax Incentive Act 2005 & No & No & No & No & No & No & No \\
\hline $\begin{array}{l}48 \text { : U.S Hazardous Liquid Pipeline Safety } \\
\text { Act of } 1979\end{array}$ & No & No & No & No & No & No & Yes \\
\hline $\begin{array}{l}49 \text { : U.S Pipeline Safety, Regulatory } \\
\text { Certainty, And Job Creation Act - PUBLIC } \\
\text { LAW 112-90 }\end{array}$ & No & No & No & No & No & No & Yes \\
\hline
\end{tabular}


ANALYZING REGULATORY FRAMEWORK FOR CARBON CAPTURE AND STORAGE .

\begin{tabular}{|c|c|c|c|c|c|c|}
\hline & $\begin{array}{l}\text { A : Capital } \\
\text { Grant }\end{array}$ & $\begin{array}{c}\text { B : CCS } \\
\text { Certificate }\end{array}$ & $\begin{array}{l}\text { C: Contract for } \\
\text { Diffrence }\end{array}$ & $\begin{array}{l}\mathrm{D}: \text { Emissions } \\
\text { and Tax Credits }\end{array}$ & $\begin{array}{c}\text { E: Loan } \\
\text { Guarantees }\end{array}$ & $\begin{array}{c}\mathrm{F}: \text { Price } \\
\text { Mechanism }\end{array}$ \\
\hline $\begin{array}{l}1: \text { Alberta CARBON CAPTURE } \\
\text { AND STORAGE ACT }+ \\
\text { Amendment Regulation }\end{array}$ & Yes & No & No & No & No & No \\
\hline $\begin{array}{l}2: \text { Alberta CARBON } \\
\text { SEQUESTRATION TENURE } \\
\text { REGULATION }\end{array}$ & No & No & No & No & No & No \\
\hline $\begin{array}{l}3 \text { : Alberta CLIMATE CHANGE } \\
\text { AND EMISSIONS } \\
\text { MANAGEMENT ACT }\end{array}$ & Yes & No & No & Yes & No & No \\
\hline $\begin{array}{l}\text { 4: Alberta CLIMATE } \\
\text { LEADERSHIP ACT }\end{array}$ & No & No & No & Yes & No & Yes \\
\hline $\begin{array}{l}5: \text { Alberta ENVIRONMENTAL } \\
\text { PROTECTION AND } \\
\text { ENHANCEMENT ACT }\end{array}$ & No & No & No & No & No & No \\
\hline $\begin{array}{l}6: \text { Alberta METALLIC AND } \\
\text { INDUSTRIAL MINERALS } \\
\text { TENURE REGULATION }\end{array}$ & No & No & No & No & No & No \\
\hline $7:$ Alberta Mines and Minerals Act & No & No & No & No & No & No \\
\hline $\begin{array}{l}\text { 8: Alberta OIL AND GAS } \\
\text { CONSERVATION ACT }\end{array}$ & No & No & No & No & No & No \\
\hline $\begin{array}{l}9: \text { Alberta OIL SANDS } \\
\text { EMISSIONS LIMIT ACT }\end{array}$ & No & No & No & No & No & No \\
\hline 10 : Alberta Pipeline Act & No & No & No & No & No & No \\
\hline $\begin{array}{l}11: \text { Alberta RESPONSIBLE } \\
\text { ENERGY DEVELOPMENT ACT }\end{array}$ & No & No & No & No & No & No \\
\hline $\begin{array}{l}\text { 12: Alberta Specified Gas Emitters } \\
\text { Regulation }\end{array}$ & No & No & No & Yes & No & No \\
\hline $\begin{array}{l}13: \text { Alberta SPECIFIED GAS } \\
\text { REPORTING REGULATION }\end{array}$ & No & No & No & No & No & No \\
\hline 14 : Alberta Surface Rights Act & No & No & No & No & No & No \\
\hline 15: Alberta WATER ACT & No & No & No & No & No & No \\
\hline $\begin{array}{l}\text { 16: Canada Emission Incentive } \\
\text { Agency Act }\end{array}$ & No & Yes & No & Yes & No & No \\
\hline $\begin{array}{l}17 \text { : Canada Kyoto Protocol } \\
\text { Implementation Act }\end{array}$ & No & No & No & No & No & Yes \\
\hline $\begin{array}{l}18: \text { Canada Oil and Gas Operations } \\
\text { Act }\end{array}$ & No & No & No & No & No & No \\
\hline $\begin{array}{l}19 \text { : Canada Reduction of Carbon } \\
\text { Dioxide Emissions from Coal-fired } \\
\text { Generation of Electricity Regulation }\end{array}$ & No & No & No & No & No & No \\
\hline $\begin{array}{l}20: \text { Canadian Environmental } \\
\text { Assessment Act }\end{array}$ & No & No & No & No & No & No \\
\hline $\begin{array}{l}21 \text { : North Dakota Century Code } 49- \\
\text { 19- } 01\end{array}$ & No & No & No & No & No & No \\
\hline $\begin{array}{l}22: \text { North Dakota Century Code } 57 \\
-39.2\end{array}$ & No & No & No & Yes & No & No \\
\hline $\begin{array}{l}23: \text { North Dakota Century Code } 57 \\
-60\end{array}$ & Yes & No & No & Yes & No & No \\
\hline $\begin{array}{l}24 \text { : North Dakota Century Code 57- } \\
51.1\end{array}$ & No & No & No & Yes & No & No \\
\hline $\begin{array}{l}25: \text { North Dakota GEOLOGIC } \\
\text { STORAGE OF CARBON } \\
\text { DIOXIDE Article 43-05 }\end{array}$ & No & No & No & No & Yes & No \\
\hline
\end{tabular}


Mac OSAZUWA-PETERS, Margot HURLBERT

\begin{tabular}{|c|c|c|c|c|c|c|}
\hline $\begin{array}{l}26: \text { North Dakota SENATE BILL } \\
\text { NO. } 2034 \text { Sub } 5+\text { Amendment }\end{array}$ & No & No & No & No & No & No \\
\hline $\begin{array}{l}27 \text { : North Dakota SENATE BILL } \\
\text { NO. } 2095\end{array}$ & No & Yes & No & No & No & No \\
\hline $\begin{array}{l}28 \text { : North Dakota SENATE BILL } \\
\text { NO. } 2139\end{array}$ & No & No & No & No & No & No \\
\hline $\begin{array}{l}29 \text { : Saskatchewan Crown Minerals } \\
\text { Act }\end{array}$ & No & No & No & No & No & No \\
\hline $\begin{array}{l}30 \text { : Saskatchewan Environmental } \\
\text { Management and Protection Act }\end{array}$ & No & No & No & No & No & No \\
\hline $\begin{array}{l}\text { 31: Saskatchewan Management and } \\
\text { Reduction of Greenhouse Gases Act }\end{array}$ & Yes & No & No & No & Yes & Yes \\
\hline $\begin{array}{l}2: \text { Saskatchewan OIL AND GAS } \\
\text { CONSERVATION } \\
\text { REGULATIONS }\end{array}$ & No & No & No & No & No & No \\
\hline 33 : Saskatchewan Pipeline Act & No & No & No & No & No & No \\
\hline $\begin{array}{l}34 \text { : Saskatchewan -The Crown Oil } \\
\text { and Gas Royalty Regulation }\end{array}$ & No & No & No & Yes & No & No \\
\hline $\begin{array}{l}35 \text { : Saskatchewan The } \\
\text { Environmental Assessment Act }\end{array}$ & No & No & No & No & No & No \\
\hline 36 : Texas House Bill HB 149 & No & No & No & No & No & No \\
\hline 37 : Texas House Bill HB 1796 & Yes & Yes & No & Yes & No & Yes \\
\hline 38 : Texas House Bill HB 469 & No & Yes & No & Yes & No & No \\
\hline 39 : Texas House Bill SB 1387 & No & No & No & No & Yes & No \\
\hline $\begin{array}{l}40 \text { : U.S Accountable Pipeline } \\
\text { Safety and Partnership Act of } 1996\end{array}$ & No & No & No & No & No & No \\
\hline $\begin{array}{l}41 \text { : U.S Carbon Pollution Emission } \\
\text { Guidelines for Existing Stationary } \\
\text { Sources- Electric Utility Generating } \\
\text { Units } 80 \text { FR } 205\end{array}$ & No & No & No & No & No & No \\
\hline 42 : U.S Clean Air Act & No & No & No & No & No & No \\
\hline $\begin{array}{l}43 \text { : U.S Energy Improvement and } \\
\text { Extension Act House Resolution } \\
\text { H.R } 6049\end{array}$ & Yes & No & No & No & No & No \\
\hline $\begin{array}{l}44 \text { : U.S ENERGY } \\
\text { IMPROVEMENT AND } \\
\text { EXTENSION ACT OF } 2008+45 Q \\
\text { Amendment }\end{array}$ & No & No & No & Yes & No & No \\
\hline $\begin{array}{l}45: \text { U.S Energy Independence and } \\
\text { Security Act }\end{array}$ & No & No & No & No & No & No \\
\hline $\begin{array}{l}46: \text { U.S ENERGY POLICY ACT } \\
\text { OF } 2005\end{array}$ & Yes & No & No & Yes & Yes & No \\
\hline $\begin{array}{l}47 \text { : U.S Energy Tax Incentive Act } \\
2005\end{array}$ & No & No & No & Yes & No & No \\
\hline $\begin{array}{l}48 \text { : U.S Hazardous Liquid Pipeline } \\
\text { Safety Act of } 1979\end{array}$ & No & No & No & No & No & No \\
\hline $\begin{array}{l}49 \text { : U.S Pipeline Safety, Regulatory } \\
\text { Certainty, And Job Creation Act - } \\
\text { PUBLIC LAW } 112-90\end{array}$ & No & No & No & No & No & No \\
\hline
\end{tabular}


ANALYZING REGULATORY FRAMEWORK FOR CARBON CAPTURE AND STORAGE .

\begin{tabular}{|c|c|c|}
\hline & A : Benefit Sharing & $\begin{array}{l}\text { B : Public Engagement and } \\
\text { Stakeholder Involvement }\end{array}$ \\
\hline $\begin{array}{l}\text { 1: Alberta CARBON CAPTURE AND STORAGE ACT + } \\
\text { Amendment Regulation }\end{array}$ & No & Yes \\
\hline $\begin{array}{l}\text { 2: Alberta CARBON SEQUESTRATION TENURE } \\
\text { REGULATION }\end{array}$ & No & No \\
\hline $\begin{array}{l}3: \text { Alberta CLIMATE CHANGE AND EMISSIONS } \\
\text { MANAGEMENT ACT }\end{array}$ & No & Yes \\
\hline 4 : Alberta CLIMATE LEADERSHIP ACT & No & No \\
\hline $\begin{array}{l}5: \text { Alberta ENVIRONMENTAL PROTECTION AND } \\
\text { ENHANCEMENT ACT }\end{array}$ & No & Yes \\
\hline $\begin{array}{l}\text { 6: Alberta METALLIC AND INDUSTRIAL MINERALS } \\
\text { TENURE REGULATION }\end{array}$ & No & No \\
\hline 7 : Alberta Mines and Minerals Act & No & No \\
\hline 8: Alberta OIL AND GAS CONSERVATION ACT & No & Yes \\
\hline 9: Alberta OIL SANDS EMISSIONS LIMIT ACT & No & No \\
\hline 10: Alberta Pipeline Act & No & No \\
\hline 11 : Alberta RESPONSIBLE ENERGY DEVELOPMENT ACT & No & Yes \\
\hline 12: Alberta Specified Gas Emitters Regulation & No & No \\
\hline 13 : Alberta SPECIFIED GAS REPORTING REGULATION & No & No \\
\hline 14 : Alberta Surface Rights Act & No & No \\
\hline 15 : Alberta WATER ACT & No & No \\
\hline 16: Canada Emission Incentive Agency Act & No & No \\
\hline 17 : Canada Kyoto Protocol Implementation Act & No & No \\
\hline 18: Canada Oil and Gas Operations Act & No & No \\
\hline $\begin{array}{l}\text { 19: Canada Reduction of Carbon Dioxide Emissions from Coal- } \\
\text { fired Generation of Electricity Regulation }\end{array}$ & No & No \\
\hline 20 : Canadian Environmental Assessment Act & No & Yes \\
\hline 21 : North Dakota Century Code 49-19- 01 & No & No \\
\hline 22 : North Dakota Century Code $57-39.2$ & No & No \\
\hline 23 : North Dakota Century Code 57 - 60 & No & No \\
\hline 24 : North Dakota Century Code 57-51.1 & No & No \\
\hline $\begin{array}{l}25 \text { : North Dakota GEOLOGIC STORAGE OF CARBON } \\
\text { DIOXIDE Article } 43-05\end{array}$ & No & Yes \\
\hline $\begin{array}{l}26: \text { North Dakota SENATE BILL NO. } 2034 \text { Sub } 5+ \\
\text { Amendment }\end{array}$ & No & No \\
\hline 27 : North Dakota SENATE BILL NO. 2095 & No & Yes \\
\hline 28 : North Dakota SENATE BILL NO. 2139 & No & No \\
\hline
\end{tabular}




\section{Mac OSAZUWA-PETERS, Margot HURLBERT}

\begin{tabular}{|c|c|c|}
\hline 29: Saskatchewan Crown Minerals Act & No & No \\
\hline $\begin{array}{l}30 \text { : Saskatchewan Environmental Management and Protection } \\
\text { Act }\end{array}$ & No & No \\
\hline $\begin{array}{l}\text { 31: Saskatchewan Management and Reduction of Greenhouse } \\
\text { Gases Act }\end{array}$ & No & No \\
\hline $\begin{array}{l}32: \text { Saskatchewan OIL AND GAS CONSERVATION } \\
\text { REGULATIONS }\end{array}$ & No & No \\
\hline 33 : Saskatchewan Pipeline Act & No & Yes \\
\hline 34 : Saskatchewan -The Crown Oil and Gas Royalty Regulation & No & No \\
\hline 35 : Saskatchewan The Environmental Assessment Act & No & No \\
\hline 36 : Texas House Bill HB 149 & No & No \\
\hline 37 : Texas House Bill HB 1796 & No & No \\
\hline 38 : Texas House Bill HB 469 & No & No \\
\hline 39: Texas House Bill SB 1387 & No & No \\
\hline $\begin{array}{l}40 \text { : U.S Accountable Pipeline Safety and Partnership Act of } \\
1996\end{array}$ & No & Yes \\
\hline $\begin{array}{l}41 \text { : U.S Carbon Pollution Emission Guidelines for Existing } \\
\text { Stationary Sources- Electric Utility Generating Units } 80 \text { FR } 205\end{array}$ & No & No \\
\hline 42 : U.S Clean Air Act & No & No \\
\hline $\begin{array}{l}43 \text { : U.S Energy Improvement and Extension Act House } \\
\text { Resolution H.R } 6049\end{array}$ & No & No \\
\hline $\begin{array}{l}44 \text { : U.S ENERGY IMPROVEMENT AND EXTENSION ACT } \\
\text { OF } 2008+45 \text { Q Amendment }\end{array}$ & No & No \\
\hline 45 : U.S Energy Independence and Security Act & Yes & No \\
\hline 46 : U.S ENERGY POLICY ACT OF 2005 & No & No \\
\hline 47 : U.S Energy Tax Incentive Act 2005 & No & No \\
\hline 48 : U.S Hazardous Liquid Pipeline Safety Act of 1979 & No & No \\
\hline $\begin{array}{l}49 \text { : U.S Pipeline Safety, Regulatory Certainty, And Job Creation } \\
\text { Act - PUBLIC LAW } 112-90\end{array}$ & No & No \\
\hline
\end{tabular}




\begin{tabular}{|c|c|c|c|c|c|c|c|}
\hline Reference & $\begin{array}{c}\text { Legal } \\
\text { Authority } \\
=\text { Alberta } \\
\text { (15) }\end{array}$ & $\begin{array}{c}\text { Legal } \\
\text { Authority } \\
=\text { Canada } \\
\text { (5) }\end{array}$ & $\begin{array}{c}\text { Legal } \\
\text { Authority } \\
\text { = North } \\
\text { Dakota } \\
(8)\end{array}$ & $\begin{array}{c}\text { Legal } \\
\text { Authority = } \\
\text { Saskatchewan } \\
\text { (7) }\end{array}$ & $\begin{array}{c}\text { Legal } \\
\text { Authority } \\
=\text { Texas } \\
\text { (4) }\end{array}$ & $\begin{aligned} & \text { Legal } \\
& \text { Authority } \\
&=\text { U.S (10) }\end{aligned}$ & $\begin{array}{c}\text { Total } \\
(49)\end{array}$ \\
\hline Capital Grant & 3 & 0 & 1 & 3 & 4 & 10 & 21 \\
\hline CCS Certificate & 0 & 1 & 1 & 0 & 4 & 0 & 6 \\
\hline Contract for Diffrence & 0 & 0 & 0 & 0 & 0 & 0 & 0 \\
\hline Emissions and Tax Credit & 7 & 3 & 9 & 1 & 4 & 10 & 34 \\
\hline Loan Guarantees & 0 & 0 & 1 & 3 & 1 & 2 & 7 \\
\hline Price Mechanism & 11 & 2 & 0 & 3 & 1 & 0 & 17 \\
\hline Capture & 20 & 11 & 1 & 10 & 4 & 16 & 62 \\
\hline $\begin{array}{l}\text { Closure, Post-closure and } \\
\text { Decommission }\end{array}$ & 20 & 0 & 0 & 0 & 1 & 0 & 21 \\
\hline $\mathrm{CO}_{2}$ Classification & 0 & 0 & 0 & 0 & 0 & 0 & 0 \\
\hline $\mathrm{CO}_{2}$ Injection & 32 & 0 & 6 & 3 & 2 & 1 & 44 \\
\hline Site selection & 0 & 0 & 0 & 0 & 4 & 0 & 4 \\
\hline Storage and Long-term Liabilities & 13 & 0 & 18 & 1 & 22 & 5 & 59 \\
\hline Transport & 13 & 0 & 2 & 4 & 1 & 4 & 24 \\
\hline Benefit Sharing & 0 & 0 & 0 & 0 & 0 & 1 & 1 \\
\hline $\begin{array}{l}\text { Public Engagement and } \\
\text { Stakeholder Involvement }\end{array}$ & 9 & 4 & 4 & 1 & 0 & 1 & 19 \\
\hline Total & 128 & 21 & 43 & 29 & 48 & 50 & 319 \\
\hline
\end{tabular}

Financials

Provisions coded in this category are those that have some influence on the economics of CCS. This category has 6 case-node which are described below:

1. Capital Grant: When governments support for capital projects are enshrined in regulations, these provisions are coded to this case-node. Any type of direct funding, especially from government, which are aimed at supporting certain capital projects, of which CCS projects may qualify, are capital grants. These funds mostly support demonstrations and first-mover projects, supplement or match funding from other sources. When such funding is enshrined in regulation, that provision is coded to this casenode.

2. CCS Certificate: A CCS certificate is a contract that utilizes a 'quantity instrument' approach to drive action. In CCS, this can be a contract that guarantee certain payments would be made if parties involved generate certain amounts of power through clean coal, capture or store certain amounts of $\mathrm{CO}_{2}$. It could also be tradeable certificates between parties in a carbon market. The key is the existence of contracts and the use of quantity instruments. Provisions that cover such issues or lay the framework on which such issues are carried are coded to this case-node. 


\section{Mac OSAZUWA-PETERS, Margot HURLBERT}

3. Contract of Difference: Contracts of Difference (CfD) are incentive mechanisms aimed to cover for losses in income for fossil fuel power generators over a set period of time as jurisdictions ramp up their share of renewables or other sources. It ensures that conventional plants do not become stranded assets as these other sources are developed and provides certainty in investments. If provisions exist in the regulations that covers for such potential losses, those sections of the regulations are coded to this casenode.

4. Tax Credits and emissions trading: This is a fee-based system where an emissions baseline is set and organizations staying below this baseline receives some credit while those above the baseline are taxed or buy credits from others who are below the baseline. This case-node will also cover aspects such as green bonds, royalty relief, tax breaks and other forms of incentives that impacts a facility's tax burden or facilitate trading in emissions. Provisions in the regulation which recognizes or facilitates such arrangements are coded to this case.

5. Loan Guarantees: These arrangements basically mean government underwrite CCS projects. These cover financial risks arising from CCS projects. Governments acts as either a party to the project or as a third party, to cover for potential liabilities arising from CCS projects in cases of failures. This way, financial risk exposure is minimized, and certainty is provided to financial institutions funding CCS projects. All provisions in the regulations which deal with such arrangements are coded to this node.

6. Price Mechanisms: This node will cover regulations which make provisions for, facilitate, or support carbon trading through mechanisms or programs utilizing some form of price systems, including cap and trade and carbon tax.

Technical

Provisions coded in this category are those that have some influence on the technical and operational aspects of CCS. This category has 7 case-node which are described below:

1. Capture: Provisions which set guidelines for CCS capture activities including permits to capture and utilize $\mathrm{CO}_{2}$, risk assessment and safety requirements are coded to this case-node. All provisions stimulating, facilitating and supporting CCS capture activities are coded to this case-node.

2. Closure, Post-closure and Decommissioning: This case-node relates to issues of liability for $\mathrm{CO}_{2}$ storage systems, site remediation and reclamation, permits, monitoring, risk assessment and safety of $\mathrm{CO}_{2}$ storage sites. Any regulation with provisions for actions to obtain a closure certificate or the criteria for transfer of responsibility after $\mathrm{CO}_{2}$ storage site is closed is coded to this case-node.

3. $\mathrm{CO}_{2}$ Classification: This case-node will cover all references to guidelines for how $\mathrm{CO}_{2}$ in $\mathrm{CCS}$ processes, at various stages and states (liquid, gas or otherwise) are classified. Specific classification and references to issues which may arise from classification challenges, such as transboundary movement of $\mathrm{CO}_{2}$ are covered by this case-node.

4. $\mathrm{CO}_{2}$ Injection: This involves aspects of the CCS process including measures for obtaining permits for safe injection of $\mathrm{CO}_{2}$ underground or for enhanced oil recovery (EOR). It also involves measurement and verification activities as well as stewardship/accountability for all processes preinjection, during injection and post-injection of $\mathrm{CO}_{2}$, including determination of storage capacity, leakage and other safety measures.

5. Transport: This case-node will cover issues related to how $\mathrm{CO}_{2}$ is transported, including common carrier issues or hub-transport agreements, the safety requirements for different modes of transport, measurement, verification and reporting needed to obtain permits for transportation of $\mathrm{CO}_{2}$. 
ANALYZING REGULATORY FRAMEWORK FOR CARBON CAPTURE AND STORAGE .

6. Site selection: This involves issues that cut across the entire CCS chain, including siting of a capture plant, selecting storage site, and transport. Measurement and verification as well as research are critical to this node, so is public acceptance. Any reference to these issues is coded to this case-node.

7. Storage and Long-term Liability: The issue here has to do with the long-term liability for stored carbon, not just the process of storing carbon underground. The extended time frame involved in $\mathrm{CO}_{2}$ storage creates unique uncertainties which most existing regulations may not cover, hence any provision with reference to these issues are coded to this node.

\section{Socio-Economic}

Provisions coded in this category are those that have some influence on the human, social and community/societal dimensions of CCS technology deployment. There are two case-nodes in this category. Suffice to say that both relate to improving public perception and acceptance of CCS. The two case-nodes in this category are described below:

1. Benefit Sharing: In cases where CCS projects involve EOR, revenues generated from any extra oil production can be shared in some agreeable ratio with the community. If regulations provide for such agreements or arrangements, these are coded to this sub-node.

2. Public Engagement and Stakeholder Involvement: This case-node will capture all provisions that mandate, facilitates or contributes to community involvement in CCS project, from planning to commissioning. 


\section{APPENDIX VI. Literature used for Figure 3}

Agerup M. (2013), Norway: legal and regulatory CCS framework, Norwegian Ministry of Petroleum and Energy, https://www.slideshare.net/globalccs/ccs-edinburghmai13 [12.03.2020].

Bonham S., Chrysostomidis I. (2012), Regulatory challenges and key lessons learned from real world development of CCS projects, Environmental Resources Management (ERM), http://www.co2captureproject.org/reports/regulatory_study.pdf [12.03.2020].

Bonham S., Chrysostomidis I., Crombie M., Burt D., van Greco C., Lee A. (2014), Local community benefit sharing mechanisms for CCS projects, "Energy Procedia", vol. 63, pp. 8177-8184.

Bui M., Adjiman C., Bardow A., Anthony E., Boston A., Brown S., .., Dowell N. (2018), Carbon capture and storage (CCS). The way forward, "Energy \& Environmental Science", vol. 11 no. 5, pp. 1062-1176.

Carbon Markets Watch (2016), Carbon markets in the post Paris world, Carbon Market Watch Briefing, https://carbonmarketwatch.org/publications/policy-brief-carbon-markets-inthe-post-paris-world/ [12.03.2020].

de Figueiredo M. (2007), The liability of carbon dioxide storage, $\mathrm{PhD}$ dissertation, Massachusetts Institute of Technology, https://sequestration.mit.edu/pdf/Mark_de_Figueiredo_PhD_Dissertation.pdf [12.03.2020].

Durrant N. (2010), Carbon capture and storage laws in Australia. Project facilitation or a precautionary approach?, "Environmental Liability", vol. 18 no. 4, pp. 148-157 [12.03.2020].

Energy Futures Initiative (EFI) (2018), Advancing large scale carbon management: expansion of the $45 \mathrm{Q}$ tax credit, https://static1.squarespace.com/static/58ec123cb3db2bd94e057628/t/5b0604f30e2e7287abb8 f3c1/1527121150675/45Q_EFI_5.23.18.pdf [12.03.2020].

Germanwatch, NewClimate Institute (2018), Aligning investments with the Paris Agreement Temperature Goal. Challenges and opportunities for multilateral development banks, https://newclimate.org/wp-content/uploads/2018/09/MDB_WorkingPaper_2018-09.pdf [12.03.2020].

Global CCS Institute (2018), The Global status of CCS: 2017, https://www.globalccsinstitute.com/wp-content/uploads/2018/12/2017-Global-StatusReport.pdf [12.03.2020].

Government of Australia (2005), Carbon dioxide capture and geological storage. Australian regulatory guiding principles, Ministerial Council on Mineral and Petroleum Resources, 
https://www.industry.gov.au/data-and-publications/regulatory-guiding-principles-for-carbondioxide-capture-and-geological-storage [12.03.2020].

Intergovernmental Panel on Climate Change (IPCC) (2018), Global warming of $1.5^{\circ} \mathrm{C}$. Summary for policy makers, https://www.ipcc.ch/sr15/ [12.03.2020].

International Energy Agency (IEA) (2012), A policy strategy for carbon capture and storage, IEA, Paris, https://www.iea.org/reports/a-policy-strategy-for-carbon-capture-and-storage [12.03.2020].

IEA (2013), Technology development roadmap: carbon capture and storage, IEA, Paris, https://www.iea.org/publications/freepublications/publication/TechnologyRoadmapCarbonC aptureandStorage.pdf [10.12.2018].

IEA (2018), Global energy \& $\mathrm{CO}_{2}$ status report 2017, IEA, Paris, https://webstore.iea.org/global-energy-co2-status-report-2017 [12.03.2020].

IEA (2018b), World Energy Outlook 2018, https://www.iea.org/reports/world-energyoutlook-2018 [12.03.2020].

International Emissions Trading Association (IETA) (2016), A vision for the market provisions of the Paris Agreement, https://www.ieta.org/resources/UNFCCC/IETA_Article_6_Implementation_Paper_May2016 .pdf [12.03.2020].

International Risk Governance Council (IRGC) (2008), Policy brief. Regulation of carbon capture and storage, https://irgc.org/issues/carbon-capture-and-storage/regulation-of-carboncapture-and-geological-storage/ [12.03.2020].

Jenkins C., Chadwick A., Hovorka S. (2015), The state of the art in monitoring and verification. Ten years on, "International Journal of Greenhouse Gas Control”, vol. 40, pp. 312-349.

Jenkins J. (2015), Financing mega-scale energy projects. A case study of The Petra Nova Carbon Capture Project, http://www.paulsoninstitute.org/wp-content/uploads/2015/10/CSPetra-Nova-EN.pdf [12.03.2020].

Kapetaki Z., Hetland J., LeGuenan T., Mikunda T., Scowcroft J. (2017), Highlights and lessons from the EU CCS demonstration project network, "Energy Procedia", vol. 114, pp. 5562-5569.

Lupion M., Javedan H., Herzog H. (2015), Challenges to commercial scale carbon capture and storage. Regulatory framework, Massachusetts Institute of Technology Working Paper Series, https://sequestration.mit.edu/pdf/2015_WorkingPaper_CCS_Regulations_Lupion.pdf [12.03.2020]. 
Marcu A. (2016), Carbon market provisions in the Paris Agreement (Article 6), Centre for Europe an Policy Studies, https://www.ceps.eu/system/files/SR\%20No\%20128\%20ACM\%20Post\%20COP21\%20Anal ysis\%20of\%20Article\%206.pdf [12.03.2020].

Odeh, N., \& Haydock, H. (n.d). International CCS Policies and Regulations Available at: https://www.globalccsinstitute.com/archive/hub/publications/162813/international-ccspolicies-regulations-WP5.1a-WP5.4-report.pdf [12.03.2020].

Robertson, K., Findsen, J., \& Messner, S. (2006). International Carbon Capture and Storage Projects Overcoming Legal Barriers. National Energy Technology Laboratory. Available at: https://www.globalccsinstitute.com/archive/hub/publications/159693/International-carboncapture-storage-projects-overcoming-legal-barriers.pdf [12.03.2020].

ter Mors E., Terwel B., Zaal M. (2014), Can monetary compensation ease the siting of CCS projects?, "Energy Procedia", vol. 63, pp. 7113-7115.

Sansom J. (2005), A regulatory perspective on carbon capture and storage in Alberta, University of Alberta School of Business, https://www.ualberta.ca/business/centres/carmen/environment/ /media/692A7D09985944F0 B3BF7A531D8C332E.ashx [12.03.2020].

Southern States Energy Board (SSEB) (2010), Carbon capture and sequestration legislation in the United States of America, https://www.sseb.org/files/ccs-legislation-condensedversion.pdf [12.03.2020].

UK Government (2018), Accelerating green finance, https://www.gov.uk/government/publications/accelerating-green-finance-green-financetaskforce-report [12.03.2020].

UK Government (2018b), $\mathrm{CO}_{2}$ transportation and storage business models, https://assets.publishing.service.gov.uk/government/uploads/system/uploads/attachment_data /file/677721/10251BEIS_CO2_TS_Business_Models_FINAL.pdf [12.03.2020]. 